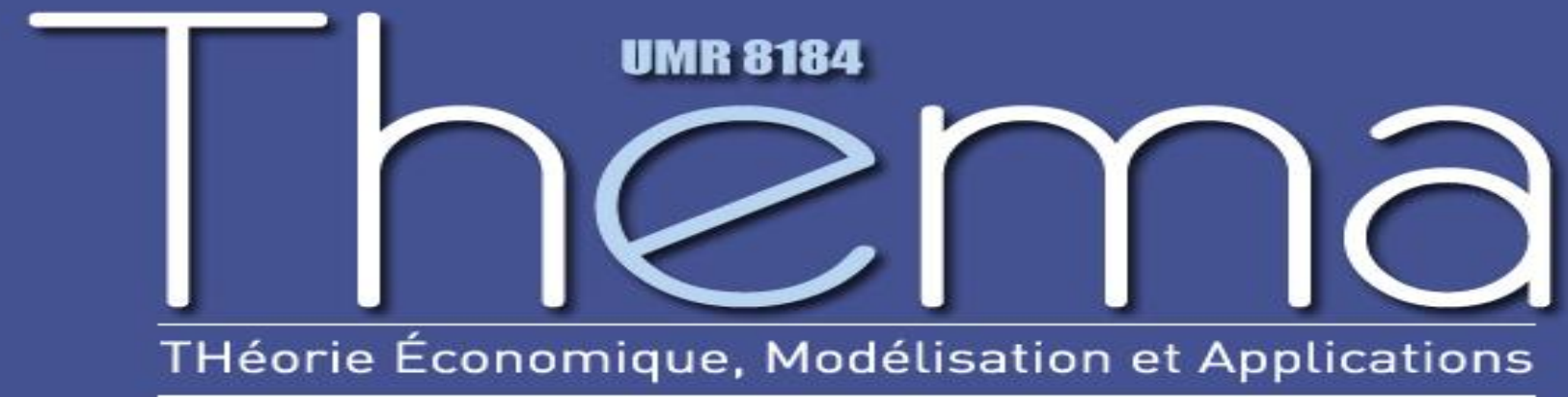

Thema Working Paper $\mathrm{n}^{\circ}$ 2014-09

Université de Cergy Pontoise, France

"Chasing the B: A Bibliographic Account of Economics' Relation to its Past, 1991-2011"

Yann Giraud

Pedro Garcia Duarte

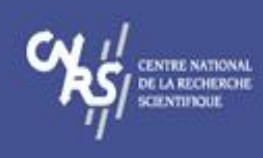

May, 2014 


\title{
Chasing the B: A Bibliographic Account of Economics' Relation to its Past, 1991-2011
}

Pedro Garcia Duarte and Yann Giraud*

(version 2, May 2014)

\begin{abstract}
:
Some historians argue that the history of economic thought (HET) is useful and important to economists and that historians should remain in economics departments. Others believe that historians' initiatives toward economists are doomed in advance to failure and that they should instead ally themselves with historians and sociologists of science located in humanities departments. Generally, the contributions that are devoted to reviewing the state of HET take a firm side for either one of these two positions and therefore have a prescriptive view on how history should be written. By contrast, our paper proposes a descriptive account of the kind of contributions to HET that have been published in major economics journals over the past two decades. To avoid definitional issues over HET, we use the B category of the JEL classification to retrieve and analyze the relevant literature. We show that, though contributions to HET are still found in top economics journals, the rate of publication of such papers has become increasingly uneven and the methods and narrative styles they adopt are increasingly remote from that advocated in the sub-disciplinary literature. For this reason, historians who are still willing to address the economics' community should be more interested in expanding the frontiers of their field rather than in trying to anticipate their targeted readers' preferences.

Keywords: history of economics, economics journals, American Economic Review, Journal of Economic Literature, Journal of Economic Perspectives, Economic Journal JEL Codes: B20, A14, B40, B29

\footnotetext{
* University of Sao Paulo, Economics Department and University of Cergy-Pontoise / THEMA, respectively. Correspondence may be addressed either to pgduarte@usp.br or to yann.giraud@ucergy.fr. We are much indebted to Joseph Persky for answering our questions on the Journal of Economic Perspectives and for commenting on an earlier draft. We also benefitted from comments by and Social Science seminar' at the University of Paris 8 and the 'History of Postwar Social Science workshop' at the LSE in December 2013. All caveats apply. Pedro Duarte thanks the University of Cergy-Pontoise / THEMA for the support and kind hospitality during his visit in 2012.
} Roger Backhouse and by participants in the 2013 HES meeting in Vancouver, the 'Economics, History
\end{abstract}


The decline of the history of economic thought - hereafter referred to as HET - as a subfield of economics is something that has been taken for granted by most historians who have attempted to reflect on the current state of their community or to look forward to its future. Take, for instance, two papers by two scholars who otherwise hold disparate views on the methodology of the history of economics: while Mark Blaug $(2001,145)$ begins by asserting that "It is no secret that the study of the history of economic thought is held in low esteem by mainstream economists and sometimes openly disparaged as a type of antiquarianism", Roy Weintraub $(2007,267)$ writes similarly that "it is not news that the history of economics is disesteemed by most economists." What differs in these two accounts, however, is the judgment that each author makes about this decline: whereas Blaug believes that the disaffection of economists toward HET is mostly a bad thing because economic theorizing is better developed when complemented by its historical context, Weintraub sees the broken relationship between economists and historians as an irreversible feature of science in the exact same way that Physics and the History of Physics are nowadays studied by scholars affiliated to two distinct departments.

This pretty much summarizes the main positions most historians of economics have held about the future of their area: on the one hand, those who argue that HET is useful and important to economists and that, therefore, historians should remain in economics departments and adopt the language of fellow economists in order to restore interest in the subfield and, on the other hand, those who believe that historians' initiatives toward economists are doomed in advance to fail and that they should instead ally themselves with historians and sociologists of science located in

\footnotetext{
${ }^{1}$ Though the decline of HET has been often evoked in recent years, in special issues and symposia of history journals (see for instance Weintraub 2002 and Tubaro and Angner 2008) as well as in numerous sessions of conferences and meetings devoted to the field, it is arguable that the rhetoric of decline is an older tradition in HET, as exemplified in Boulding's question "After Samuelson, who needs Adam Smith?" (Boulding 1971) and Samuelson's assertion that "When [he] began graduate study a million years ago, history of thought was a dying industry" (Samuelson 1987, 51) (see also Goodwin 2008). In fact the decline of HET in US graduate programs was already discussed in the introduction to the first issue of History of Political Economy in 1969 (Goodwin, Spengler and Smith 1969). In a similar vein A. W. Coats $(1969,9-10)$ noted the contradictory features of history of economics, which had declining pedagogical importance and growth of research: "The explosion of research and publication, and the economists' increasing involvement in business and governmental affairs, have combined to put such pressure on the curriculum that academic economists nowadays regard the history of their discipline either as an unnecessary luxury or, more frequently, as a wasteful diversion of time and energy from more immediately productive pursuits... However, the state of research in the history of economic thought is much more encouraging than the teaching situation."
} 
humanities departments. ${ }^{2}$ In fact, with a few notable exceptions - e.g. Goodwin 2008; Backhouse and Fontaine, forthcoming -, almost all the contributions that are devoted to reviewing the state of HET end up taking a firm side for either one of these two positions. The result is that such contributions often adopt a prescriptive stance, focusing on how HET should be written rather than on how it has been written in the recent past. This is problematic because, as Weintraub (2002) points out, it is quite curious that people allegedly interested in the history of a discipline would not utilize the historians' tools when it comes to depict their own field of research. In addition, these contributions often adopt an "essentialist" tone: they try to define what they perceive as the essence of HET and, accordingly, they attempt to categorize different ways in which HET should be done. The problem with these "essentialist" accounts is that the definitions and methodologies they impose on HET will necessarily pervade their depiction of past works, therefore undermining their historiographical content. ${ }^{3}$

This paper offers a different account of HET as a subfield of economics. Instead of walking down the essentialist route, we specified a narrow focus of looking at the kind of HET that has been published in a number of mainstream economics journals in the past twenty years or so. Rather than working with a pre-established definition of HET, we let the actors themselves define it through the Journal of Economic Literature (JEL) codes assigned to the articles in our sample. In practice, we study the papers published in eight top economics journals between 1991 and 2011 under the JEL code B, "History of Economic Thought, Methodology, and Heterodox Approaches." ${ }^{4}$ We can thus characterize in a more neutral way the evolution within economics of what economists have classified as HET, not by focusing on what the economics discipline has been missing but, instead, by looking at the kind of research in HET that is still published in mainstream journals.

\footnotetext{
${ }^{2}$ As Backhouse and Fontaine (forthcoming) show, the name of the field itself is subject to controversy. While 'History of Economic Thought' is the term used in the Journal of Economic Literature classification system, scholars who argue that HET would be better placed within the larger history of science community often prefer using the term 'History of Economics'. Because in our own contribution we are not interested in defining what the essence of HET is, we will not make much of this distinction.

${ }^{3}$ Blaug (1990), though quite an influential work, is particularly characteristic of the essentialist style of historiographical writing. This is all the more problematic when the author argues that HET should remain a subfield of economics because in that case, he also has to define what the essence of economics is. See also Marcuzzo (2008) for a proposed classification of the kinds of works done in the history of economics and an appraisal of this field.

${ }^{4}$ For a full description of the $\mathrm{B}$ category and its subdivisions in the $J E L$, see Appendix A.
} 
Therefore, we attempt to locate and describe the main themes, arguments and methods used in these HET articles and thus we try to establish a descriptive methodology of HET as a subfield of economics. The issue, ultimately, is neither to verify the decline of the subfield or to lament over it but, rather, to wonder why and for what purposes (some) economists are still interested in using past ideas and authors when engaging with their fellows through publications in major economics journals. Another way to put it is to ask the question: if historians wanted to maintain their relation (even if in a rather reduced scale) with the economics profession, what kind of works would economists encourage them to produce? In section 1 we describe our methodological approach and then present our overall quantitative results in section 2, giving a few key figures on the inclusion of HET papers in mainstream economics journals. We proceed in section 3 to a closer examination of the methods and narrative styles which are found in these contributions. In section 4 we will further disaggregate our data and proceed to a more detailed and qualitative depiction of the place of HET in our surveyed journals, trying to identify for each one some specific traits and providing a few elements of contextualization. In the conclusion, we will assess whether our findings help shed some light on the debates over the future of HET.

\section{1 - Data and Methodology}

As we stated above, we want to explore the economists' engagement with the past of their discipline through articles published in major journals. We selected the top five economics journals (as most economists now perceive): ${ }^{5}$ the American Economic Review (AER), Econometrica, the Journal of Political Economy (JPE), the Quarterly Journal of Economics (QJE), and the Review of Economic Studies (REStds). Most of them are generalist journals and are run in the United States (though with a diverse editorial board). We added to this list the Economic Journal (EJ) for being a longstanding important journal which is run in Europe, and two journals that have an editorial policy of providing economists surveys and overviews of different strands of the literature (perhaps referring to past developments and authors), the Journal of Economic Literature (JEL) and the Journal of Economic Perspectives (JEP). As these

\footnotetext{
${ }^{5}$ See for instance Kalaitzidakis, Mamuneas and Stengos (2011) and Card and DellaVigna (2013).
} 
three journals are generally considered to be among the top 15 journals in economics in most rankings, we still study the papers that are published in the allegedly best journals, while also favoring journals that may be more likely to publish contributions to the history of economics. For the time span, we chose 1991-2011 because the current JEL descriptors (B000-B590) were introduced in 1991, therefore avoiding issues related to changes in the JEL nomenclature over time. ${ }^{6}$

Indeed, we would not expect to find many instantiations of historical works if we had restricted our research solely to the top five journals. This extension of our sample, though likely to result in more relevant results, is not without posing problem. It is notable, for instance, that the $J E L$ and the $J E P$ publish mostly solicited rather than submitted articles. The same thing applies to the $A E R$, whose special issue "Papers and Proceedings" includes selected papers presented at the annual meeting of the American Economic Association. This means that the network effect is expected to be stronger in these journals than in the five others, which is something that should be weighed when considering our results in the next sections. Yet it would be equally naïve to assert that network effects are absent in the other journals under consideration, as the visibility of an author in the economists' community can perhaps alter his chance to be published in these journals.

Given this set of eight journals, we retrieved through EconLit all pieces that had at least one B JEL code ("History of Economic Thought, Methodology, and Heterodox Approaches"). In other words, we did not define what we understand as being HET, but rather took what economists themselves have chosen to label (at least in part) as pertaining to the B code. ${ }^{7}$

We did not want, at this point, to eliminate from our sample those articles in the methodology of economics (B4 category) and in heterodox economics (B5 category). There are multiple justifications for doing so. As it has been noted many times (Weintraub 2007, Backhouse and Fontaine forthcoming), the development of HET as a subfield of economics was tied to issues of heterodoxy vs. orthodoxy, with

\footnotetext{
${ }^{6}$ Before 1991, the JEL classification system was numerical and not directly translatable into the current categories (though some of them were basically the same in the two systems). We opt for the 19912011 sample both because we did not want to have the trouble of defining an equivalence between systems, which could eventually distort our analysis, and also because we are interested in the HET used by economists in the most recent past.

${ }^{7}$ It is important to mention that we do not have a problem of multiple counting for one given article which has several B codes. Through EconLit (EBSCO "visual search" option) we get articles that have at least one B code, instead of selecting items by each B code. We thus avoid an important limitation in Marcuzzo's $(2008,115-6)$ analysis, as she herself recognized.
} 
many economists using the past to criticize recent developments in mainstream economics. Likewise, HET has often been attached to methodological concerns, as a number of historical contributions have followed the epistemological traditions of the likes of Karl Popper, Imre Lakatos or Thomas Kuhn by studying past developments in economics as a way to appraise the scientific character of the field. While we are aware that using the various B codes as an indication of what has been considered as "history" by the economics' profession is a somewhat reductionist methodology, it still appear to us as the best way to avoid imposing a particular conception of HET to our sample. ${ }^{8}$ Of course, as we deepen our analysis, we will discuss these subcategories a bit more, looking at what changes if we restrict our sample to the B0-B3 range.

After retrieving all articles, we classified them into the following six categories:

1 - Obituaries and biographies;

2 - Interviews;

3 - Book Reviews;

4 - Honorary pieces, prizes and announcements;

5 - Articles (including obituaries published more than 5 years after economists' death $){ }^{9}$

6 - Comments, Replies, Rejoinders, Introductions, Errata.

For categories 1,3 , and 4 , we created a subdivision: "S" for the shorter pieces (up to 3 pages) and "L" for the longer ones. For book reviews which generated a follow up commentary, this commentary was also classified in category 3 (because it originated from a book review).

We shall present the distribution of the articles in these different categories for each journal in the next section, as well as other quantitative analysis on the number of authors, among other issues. However, in order to deepen our analysis so to complement it with more qualitative elements, we limited our focus in the remaining

\footnotetext{
${ }^{8}$ We are aware that $J E L$ codes can sometimes be reported quite inappropriately: a few papers that historians of economics would obviously identify as contributions to their fields may have no B descriptor (for example, Evensky 1993), while a few items seem to mistakenly have a B-code. We chose to stick to our methodology and, thus, do not include the former and exclude the latter from our sample.

${ }^{9}$ We have decided that biographies and obituaries published more than 5 years after the person's death are to be classified in 5, as this time interval makes it more likely that the author would develop some kind of appreciation of lasting contributions of the economist, which is perhaps closer to some kind of HET than the typical obituary written immediately after the person's death.
} 
of our study to those items pertaining to categories 5 (articles).$^{10}$ For this subsample we checked each article in order to give an assessment of the methods the contributors have used when dealing with the past of their discipline and of the uses they have made of it (which we refer to as "narrative styles").

\section{2 - Overall Quantitative Results}

The following table shows, for each of the eight journals we surveyed, the number of items that are tagged with one or several B codes distributed among the categories that we have previously defined.

\begin{tabular}{|c|c|c|c|c|c|c|c|c|c|c|}
\hline & \multicolumn{2}{|r|}{1} & 2 & \multicolumn{2}{|c|}{3} & \multicolumn{2}{|r|}{4} & \multirow[t]{2}{*}{5} & \multirow[t]{2}{*}{6} & \multirow[b]{2}{*}{ Total } \\
\hline & $\mathbf{S}$ & $\mathbf{L}$ & & $\mathbf{S}$ & $\mathbf{L}$ & $\mathbf{S}$ & $\mathbf{L}$ & & & \\
\hline AER & 0 & 0 & 0 & 0 & 0 & 0 & $5(3)$ & 38 (26) & 0 & $43(29)$ \\
\hline Econometrica & 0 & 0 & 0 & 0 & 0 & 0 & 0 & $2(1)$ & 0 & $2(1)$ \\
\hline EJ & 0 & $30(30)$ & 0 & 0 & $8(4)$ & 0 & 0 & $49(28)$ & $6(4)$ & $93(66)$ \\
\hline JEL & $1(1)$ & 0 & 0 & 148 (116) & $22(19)$ & 0 & 0 & $29(23)$ & $1(0)$ & $201(159)$ \\
\hline JEP & 0 & 0 & $5(5)$ & 0 & 0 & $1(1)$ & $26(26)$ & $63(45)$ & $13(6)$ & $109(83)$ \\
\hline JPE & 0 & $10(10)$ & 0 & 0 & 0 & 0 & 3 (3) & $8(7)$ & 0 & $21(20)$ \\
\hline QJE & 0 & 0 & 0 & 0 & 0 & 0 & 0 & $5(5)$ & 0 & $5(5)$ \\
\hline REStud & 0 & 0 & 0 & 0 & 0 & 0 & 0 & $1(0)$ & 0 & $1(0)$ \\
\hline Total & $1(1)$ & $40(40)$ & $5(5)$ & $148(116)$ & $30(23)$ & $1(1)$ & $34(32)$ & $196(135)$ & $20(10)$ & $475(363)$ \\
\hline
\end{tabular}

Table 1: Number of B-code items published between 1991 and 2011 in 8 top journals in economics

The figures show that over the period we studied, 475 items tagged with Bcategory have been published in the eight journals we surveyed (which corresponds roughly to five percent of all articles published in these journals). Yet only 196 of them (a bit more than forty percent) are research articles per se (category 5). Most of the difference is explained by the presence of a high number of book reviews (category 3 ) of historical or methodological works published in the JEL over the years as well as a few book reviews published in the EJ. Among journal specificities, we also see a number of obituaries published with a $\mathrm{B} J E L$ descriptor in the JPE and a higher number of Prize announcements and honorary pieces (category 4 ) in the JEP,

\footnotetext{
${ }^{10}$ For most journals in our sample there is no qualitative difference between the temporal occurrence of HET pieces in all categories and those in category 5 only. And small quantitative differences occur in the AER, the EJ, and the JPE. For the AER this is due to the publication of a few Nobel lectures, categorized as $4 \mathrm{~L}$ (only 5 occurrences in total). For the EJ, this is due to a few items in category 6 , and the JPE due to a few Nobel lectures and a special issue in 1993 with reminiscences on George Stigler (who died in December of 1991) - here categorized as "1L".
} 
with a few published in $A E R$ and $J P E$ - these consist, respectively, of Nobel Prize lectures and pieces written in honor of both Nobel Prize winners and of John Bates Clark medal recipients.

In Table 1 we also report in parenthesis the numbers when we exclude from our sample items that had B4 (economic methodology) and B5 (current heterodox approaches) descriptors with no other B code. These would possibly be items more clearly defined with methodology and heterodoxy perhaps without historical content. The overall picture remains qualitatively the same as when we use the entire sample: the three major journals that published historical pieces remain $J E L, J E P$ and $E J$; a bit less than forty percent of the 363 items are research articles and another forty percent are book reviews (mostly published in the $J E L$ ). In what follows, we will usually consider the entire sample and will highlight relevant differences for this more restricted sample.

The relatively high number of honorary pieces in the journals of our entire sample, 35 - which is more than the total number of research papers in HET (category 5) published in either in the $J E L$ or the $E J$ or the $A E R$ over the period - should inspire caution to those who want to assess the vitality of the history of economics by simply looking at the $J E L$ descriptors. As we see here, if one identifies history of economics with an item with a B descriptor in these journals he would conflate research in the subfield with celebration of economists' achievements. In this light, if articles (category 5), longer book reviews (category 3L) and comments (category 6) testify to some deeper engagement with research in the subfield, we can count a total of such 246 contributions (roughly $2.6 \%$ of all articles published in the journals of our sample), a bit more than a half of the total items initially retrieved.

As for category 5, we can observe that among the 196 published papers, only 54 are published in the top-5 journals. It must be noted also that among the 38 papers published in the AER, 31 are located in the 'Papers and Proceedings' volumes, meaning that only 7 are not derived from presentations at the annual meeting of the Association and invited to be published. Among these 7 contributions, there are two presidential addresses and one paper celebrating the 100th birthday of the Association. Also, 3 articles in the $Q J E$ were published as part of a mini-symposium on 20th century economics. Therefore, we can assess that no more than 17 papers published in these top-5 journals were initially submitted to the editors (i.e., $30 \%$ of the research papers they published in this period). Among the top-5, the $J P E$ seems to 
be the most inclined to published papers in the history or methodology of economics with a number of 8 articles while the REStud seems to be the least historically inclined with only one paper - one which is not particularly historical, as we will see in the next section. Outside of the top-5, though there is at least one journal which published a high number of historical or methodological refereed articles: the $E J$ with a total number of 49 research papers over 20 years. Yet, as we will see below, that number has decreased significantly over the period.

Together with the decomposition of our sample into the different categories, as a way of having a better sense of the presence of past ideas and economists in mainstream journals, it is interesting to see if each item has or not only a B code. An article with only B descriptor would perhaps be more "internal" to the history of economics, methodology or heterodox communities than articles that combined a $\mathrm{B}$ descriptor with others of areas of economics (a more economics paper, in some sense). We present this evidence in Table 2.

\begin{tabular}{lcccc}
\hline & \multicolumn{2}{c}{ All articles } & \multicolumn{2}{c}{ Cat. $3 L+5+6$} \\
\cline { 2 - 5 } & $\begin{array}{c}\text { Entire } \\
\text { Sample }\end{array}$ & $\begin{array}{c}\text { Restricted } \\
\text { Sample }\end{array}$ & $\begin{array}{c}\text { Entire } \\
\text { Sample }\end{array}$ & $\begin{array}{c}\text { Restricted } \\
\text { Sample }\end{array}$ \\
\cline { 2 - 5 } AER & 48,8 & $(48,3)$ & 43,6 & $(42,3)$ \\
Econometrica & 50 & $(0)$ & 50 & $(0)$ \\
EJ & 38,7 & $(22,7)$ & 57,1 & $(41,7)$ \\
JEL & 54,7 & $(69,2)$ & 55,8 & $(69)$ \\
JEP & 45,4 & $(59)$ & 57,9 & $(51)$ \\
JPE & 42,9 & $(40)$ & 62,5 & $(57,1)$ \\
QJE & 80 & $(80)$ & 80 & $(80)$ \\
REStds & 100 & $(0)$ & 100 & $(0)$ \\
\hline
\end{tabular}

Table 2: Percentage of B-code items that had another $J E L$ descriptor of a different letter

This evidence suggests that roughly half of the B-code items in journals other than QJE and REStds have another JEL descriptor of a different letter, indicating that in them history of economics is associated with other subfields of economics. This association is much stronger in journals like QJE and REstds, but these are exceptions because these journals published very little B-code items in the period considered, 1991-2011 (5 items in QJE and 1 in REstds). When we check this percentage among the items in categories 5,3L, and 6, only, the overall figure remains qualitatively the same, but now journals like $E J, J E P$ and $J P E$ (and $J E L$ is also not much behind) have 
a substantially higher percentage of B-code items with another JEL descriptor, indicating that research articles and longer academic pieces published had a stronger link to other areas of economics. Qualitatively the same overall picture comes when we work with the restricted sample without B4 and B5 items (numbers in parentheses). ${ }^{11}$

Additionally, we can have a better sense of the evolution over time of the number of B-code publications in all 8 journals, as the next graph shows.

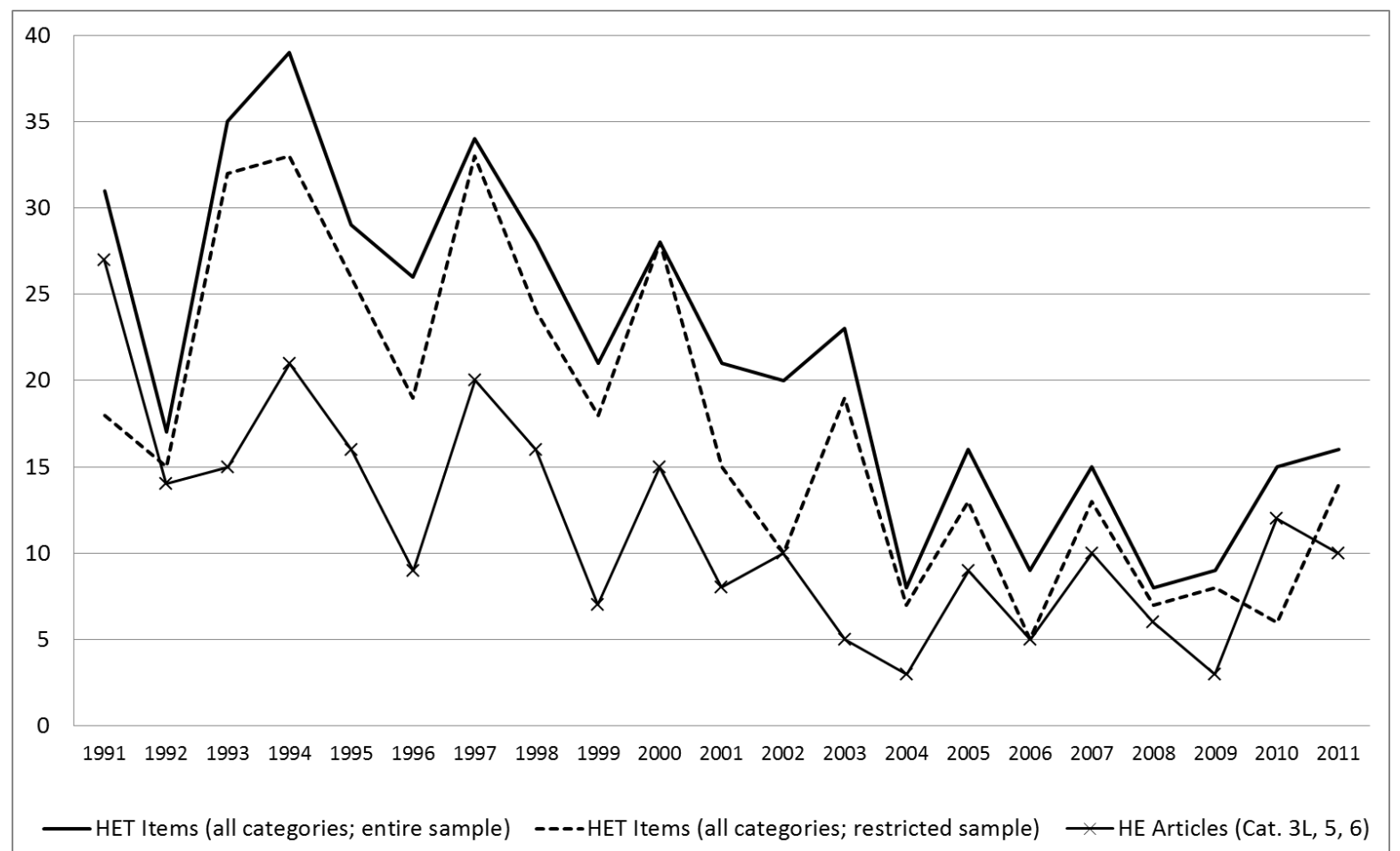

Figure 1: Number of History of Economics Articles in all Journals

What we observe is a general decrease of HET publications in all journals in the period 1991-2011, which got worse in the first half of the 2000 decade, with a mild recovery after 2008. This is particularly obvious if we only look at the pieces having a greater engagement with the subfield - articles, longer book reviews and comments (line for items in categories 3L, 5 and 6): while 27 pieces of this sort were published in 1991, there were only 3 on 2009. Of course, the decrease has been more accentuated by the falling publications of historical articles in some of the journals we surveyed, in particular the $E J$, and a mild reduction in the $A E R$ and the $J E L$. On the other hand, publications in the JEP remained more constant, though unsteady over the

\footnotetext{
${ }^{11}$ The $E J$ is an interesting case though, with much lower percentages in the restricted sample. On the other side, $J E L$ exhibits significantly higher percentages now.
} 
years (while Econometrica, QJE and REStds have had almost no room to historical articles). The next four graphs show this evolution for these journals as percentage of the total number published articles, both for the entire sample and for the restricted one (articles with only B0-B3 JEL descriptor). ${ }^{12}$ Occurrence of such publications in the other four journals is too haphazard to draw conclusions about its evolution.

\footnotetext{
${ }^{12}$ The total number of articles is found using a JSTOR search for "the" in each journal, with only "articles" as type. Note that for the $E J$, the very high percentage observed in 1991 is related to the fact that the journal was celebrating the $100^{\text {th }}$ birthday of the Royal Economic Society with a series of retrospective pieces. Similarly, peaks around 2000 partially reveal celebratory and prospective analyses of the state of economics that emerged as the $20^{\text {th }}$ century was closing.
} 


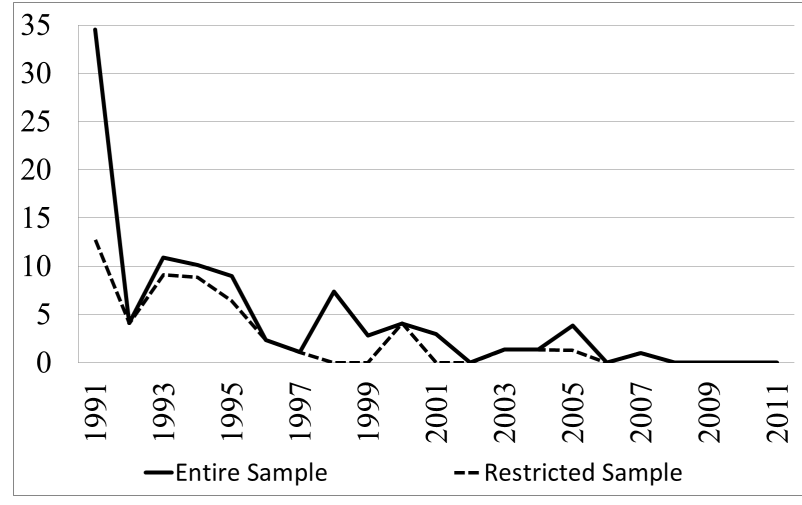

Figure 2: HET Articles (3L, 5 and 6) as Percentage of Total in the $E J$

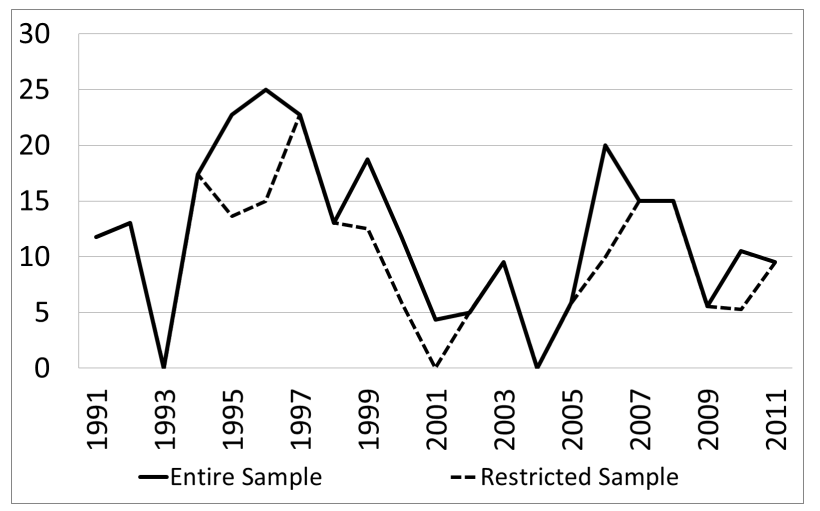

Figure 3: HET (3L, 5 and 6) as Percentage of Total in the JEL

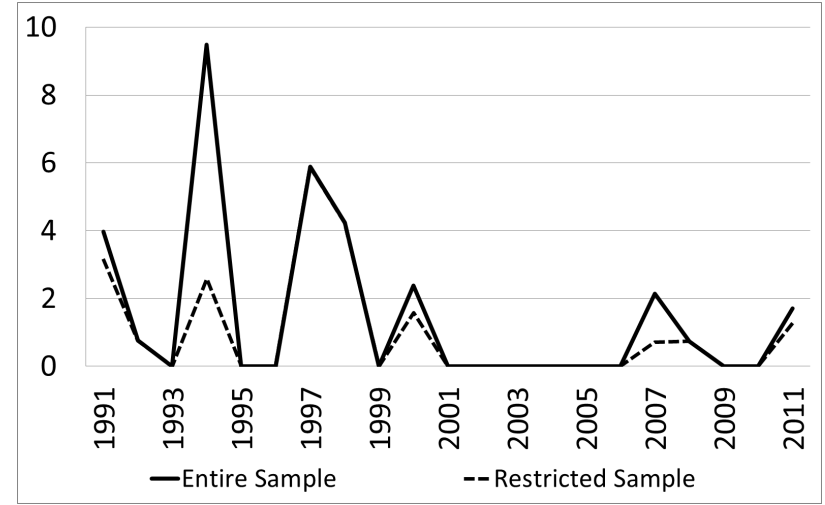

Figure 4: HET Articles (3L, 5 and 6) as Percentage of Total in the $A E R$

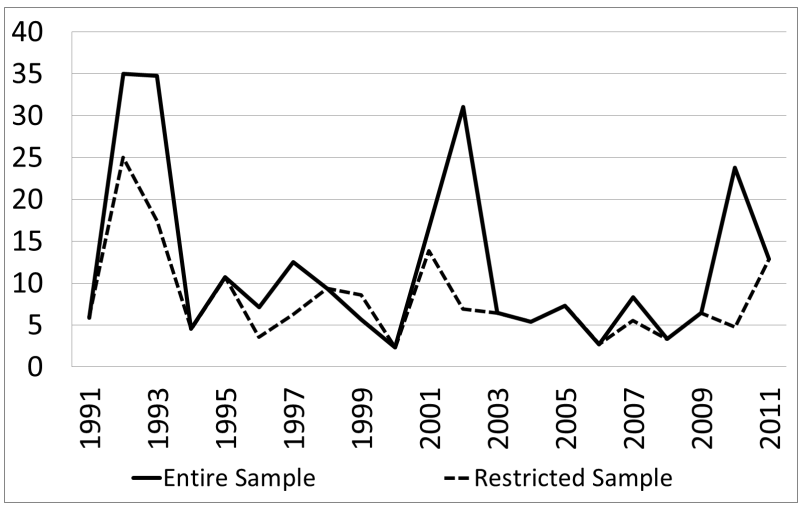

Figure 5: HET (3L, 5 and 6) Articles as Percentage of Total in the JEP

Restricting our observation solely to category 5 (research articles), we can see which sub-categories of B-codes are the more represented. ${ }^{13}$

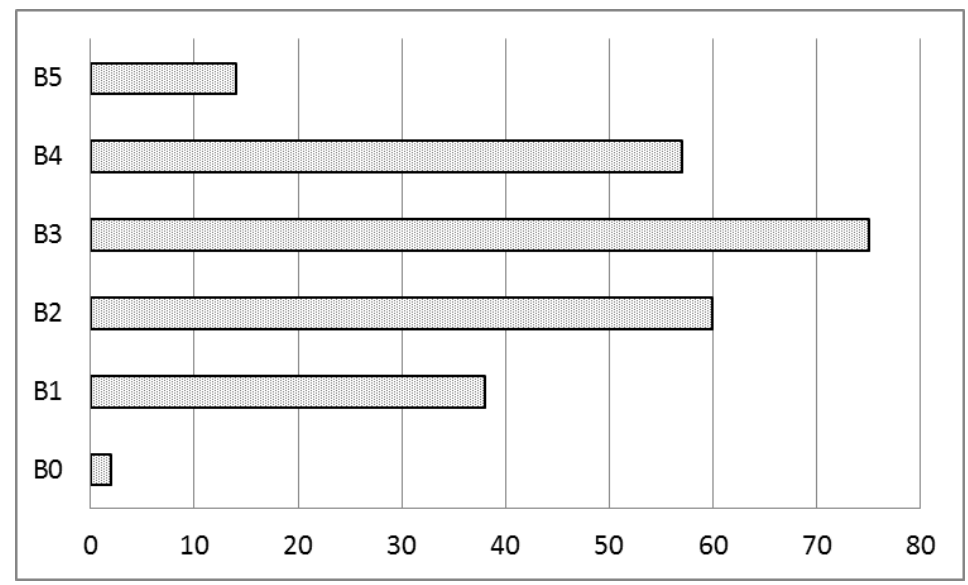

Figure 6: Number of Occurrences of B-codes in All Journals

\footnotetext{
${ }^{13}$ For a full description of the B category and its subdivisions in the $J E L$ classification system, see Appendix A.
} 


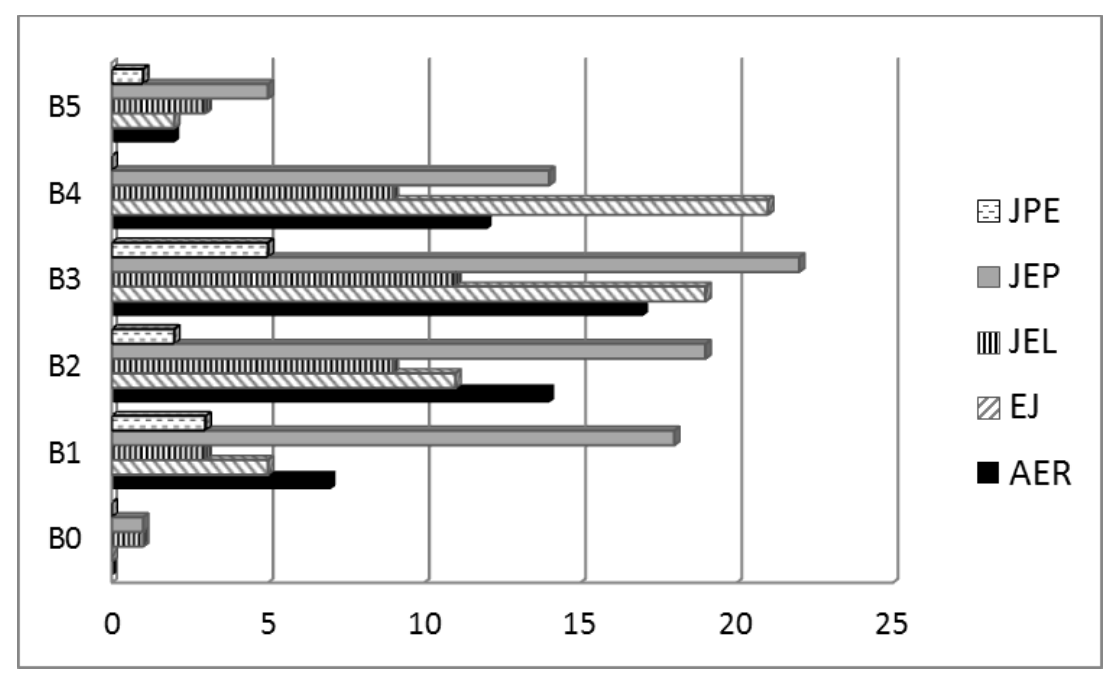

Figure 7: Number of Occurrences of B-Codes in Selected Journals

The data show that the B3 category - individuals - is the most represented, therefore signaling that these papers study the great figures of the past. B2, which includes history of economics since 1925 signals a preference for the most recent history of economics, which is not very surprising in journals that devoted to researchers interested in the more recent development of economics. By contrast, the distant past is less addressed in these papers, which is signaled by a lower number of B1 pieces. Pieces addressing issues of methodologies, which are labeled as B4, are relatively well represented among these papers. However, it is quite difficult to assert from this observation that there is a strong interest in the methodology of economics as a specialized subfield because a lot of these papers actually consist in retrospective pieces or surveys with some conclusions on methodology as opposed to full-fledged methodological pieces - more on this in the next section. Figure 6 also indicates that current heterodox approaches (B5) has relatively low presence. However, there are articles dealing with important heterodox economists that appear in B3, so that the real presence of heterodoxy in these journals should be read with caution. ${ }^{14}$ Finally, the category B0 - general - is used very rarely. Looking at these figures for some selected journals (Figure 7), it appears that there are a few specificities among journals with the $E J$ publishing a relatively higher number of $\mathrm{B} 4$ articles and the JEP having more of its HET papers, relative to the other journals, dealing with pre-1925 subjects.

\footnotetext{
${ }^{14}$ Adding the occurrence of B4 and B5 descriptors, they appear 71 times, while the sum of B0 to B3 is 175.
} 
Finally, still dealing with research papers only (category 5), we can examine more closely the authors. There are a total of 177 contributors to all 8 journals, mostly working in North-American institutions (71\%), and they are distributed among journals as follows:

\begin{tabular}{c|ccc|} 
Journal & Nbr of Authors & Nbr of 'historians' & Percentage of hist. \\
\hline AER & 38 & 9 & $24 \%$ \\
Econometrica & 2 & 2 & $100 \%$ \\
EJ & 52 & 23 & $44 \%$ \\
JEL & 28 & 15 & $54 \%$ \\
JEP & 63 & 28 & $44 \%$ \\
JPE & 10 & 6 & $60 \%$ \\
QJE & 6 & 1 & $17 \%$ \\
REStds & 2 & 0 & $0 \%$ \\
\hline All journals & 177 & 70 & $40 \%$
\end{tabular}

Table 3: Authors of HET articles in all 8 journals

Of course, some of these authors have published several papers over the surveyed time period and some of them have published in several journals. Among them, 4 authors have published in three journals and 16 have published in two of them. 30 authors have published more than one paper in at least one of the eight journals and 9 of them have published more than 2 papers. ${ }^{15}$ Also, it is notable that only a handful of articles in our sample are co-authored.

To estimate the extent to which is the authors who publish articles with a B code in top journals are tied to the community of historians of economics, we have tried to appraise the number of these contributors who have had a deeper engagement with the history of economics, as opposed to economists who would occasionally use their knowledge of the subject matter to publish a piece using or dealing with the past. To be consistent with what precedes, we have chosen to give a bibliographic answer to this question: we used the Social Sciences Citation Index (Thomson Reuters) to see whether these authors have published an article in one of the three main HET journals: History of Political Economy (HOPE), the Journal of the History of Economic Thought (JHET) and the European Journal of the History of Economic

\footnotetext{
${ }^{15}$ An exception is Joseph Persky who, as the Editor of the 'Retrospective' section in the JEP, has published seven papers in that journal.
} 
Thought (EJHET). ${ }^{16}$ Calling these authors "historians", we see that there are 70 of them among the 177 contributors, which amounts to $40 \%$ of the total. Looking at each journal, we observe notable differences: while "historians" represent $54 \%$ of all authors in the $J E L$ or $60 \%$ of authors in the $J P E$, they are only $24 \%$ in the AER or $17 \%$ in the $Q J E .{ }^{17}$ To state this differently, $76 \%$ of authors writing B-codes articles in the AER have had little - if any - engagement with HET as a subfield of economics. This can lead us to ask ourselves a number of questions: do these B-codes papers actually study the history of economics in the same way that disciplinary historians would do? And if not, what kinds of uses of the past of the economic discipline do they provide? The object of the next section is to explore these issues in more detail.

\section{3 - Methods and Narrative Styles}

When they evoke the various ways of studying the history of economics, disciplinary historians tend to follow Mark Blaug (1990)'s distinction between rational and historical reconstructions. While the former considers past economic developments from the point of view of the most recent economic theory, the latter consists in placing past economic thoughts in their original context while trying to avoid judgments over their validity for today's economists. Previous contributions to the debate on the future of HET have argued that the former, 'internalist', method should be used by historians if they want to communicate more with fellow economists whereas others have expressed their preference for the latter, 'externalist', method as the only truly historical way to give a fair account of the past of the discipline. ${ }^{18}$ Though there are several variants of this distinction - see for instance Waterman

\footnotetext{
${ }^{16}$ This is arguably a quite weak criterion in the sense that some of these authors we are calling "historians" could well be invited to contribute a piece (or to submit one, as Samuelson did more than once) in one of the HET journals without really taking part of the history of economics community. However, other criteria, such as attendance to HET meetings or listing HET among fields of specialization on personal web pages or CVs, would be equally objectionable without being as easily quantifiable.

${ }^{17}$ It is important to realize that QJE, REstds, and Econometrica are outliers in the sense of having published very little HET articles in the twenty years under analysis. Therefore, the reader should not be impressed with Econometrica for having published all pieces written by "historians". This journal has only published 2 HET articles in this period, one on Ragnar Frisch as editor of Econometrica (by Olav Bejerkholt), and another one on choice theory (by Amartya Sen) - which had a D JEL code as well.

${ }^{18}$ See Moscati (2008) as an instance of the former and Weintraub (2007) as an instance of the latter. Blaug himself embraced both ways of doing HET, using rational reconstruction to address general economics students in his Economic Theory in Retrospect, but also expressing his preference for the more historical method as he criticized Sraffian interpretations of Classical economics (Blaug 1999).
} 
(2008) -, it has framed the discourse of historians of economics when they appraise the past and future of their field. It could be tempting, therefore, to use our sample as a way to check whether HET works published in mainstream economics have tended to follow either one of those methodologies.

However, if we wanted to classify the papers in our sample using the rational vs. historical reconstruction dichotomy, we would encounter insurmountable difficulties for this distinction does not really match the practices of neither disciplinary historians nor economists involved with the past. Rather than using a distinctive and consistent methodology, the contributions we surveyed use a number of methods and adopt certain narrative styles. By 'method', we do not mean a preexisting methodological framework but, rather, recurring tools that are used in order to produce a narrative, for instance the use of one's personal memories, of mathematical or of archival materials, mostly correspondence. What we mean by 'narrative style' is the existence of some recurring types of discourses or arguments involving the history of economics; these are, in other terms, the uses economists and historians make of the past of their discipline when they publish a paper in a major economics journal.

To locate these 'methods' and 'narrative styles', we have read and summarized the 196 articles (category 5) published in all eight journals, trying to extract for each of them the main line of arguments they develop and the tools they use to do so. ${ }^{19}$ Another way to put this is that our approach is inductive. From these observations and from checking all items in category 5, we delimitated the following non-mutually exclusive types of method:

- Survey and overview: Most of the argument of the paper is based on the study of the existing literature. Sources are mentioned but specific works by economists are rarely quoted or studied at length. Instead, a bird's-eye view of the relevant literature is generally offered. In some ways, this is the weakest, least specific, type of method.

- Close reading: Specific works by past economists are quoted, interpreted and/or confronted with each other. It is mostly textual exegesis.

- Context: The author studies to some extent the institutional or social context or biographical elements surrounding the development of past economic theories but does not necessarily use specific archival materials to do so.

\footnotetext{
${ }^{19}$ An example of this work is provided for the journal JEL in Appendix B.
} 
- Archives: The author uses or mentions archival materials such as professional and personal correspondences.

- Mathematics: The author provides a mathematical formulation of past economic works, regardless of whether these works were originally expressed in a mathematical form.

- Statistics: The author uses statistical tools to account for the production of knowledge in some subfields of the discipline or to discuss the empirical significance of a theory.

- Reminiscences: The author uses his own experience as an economist to account for past developments.

- N/A: The article contains arguments that are theoretical or methodological but have little significance from a historical perspective.

The next two figures show how often these methods are used in our surveyed articles: ${ }^{20}$

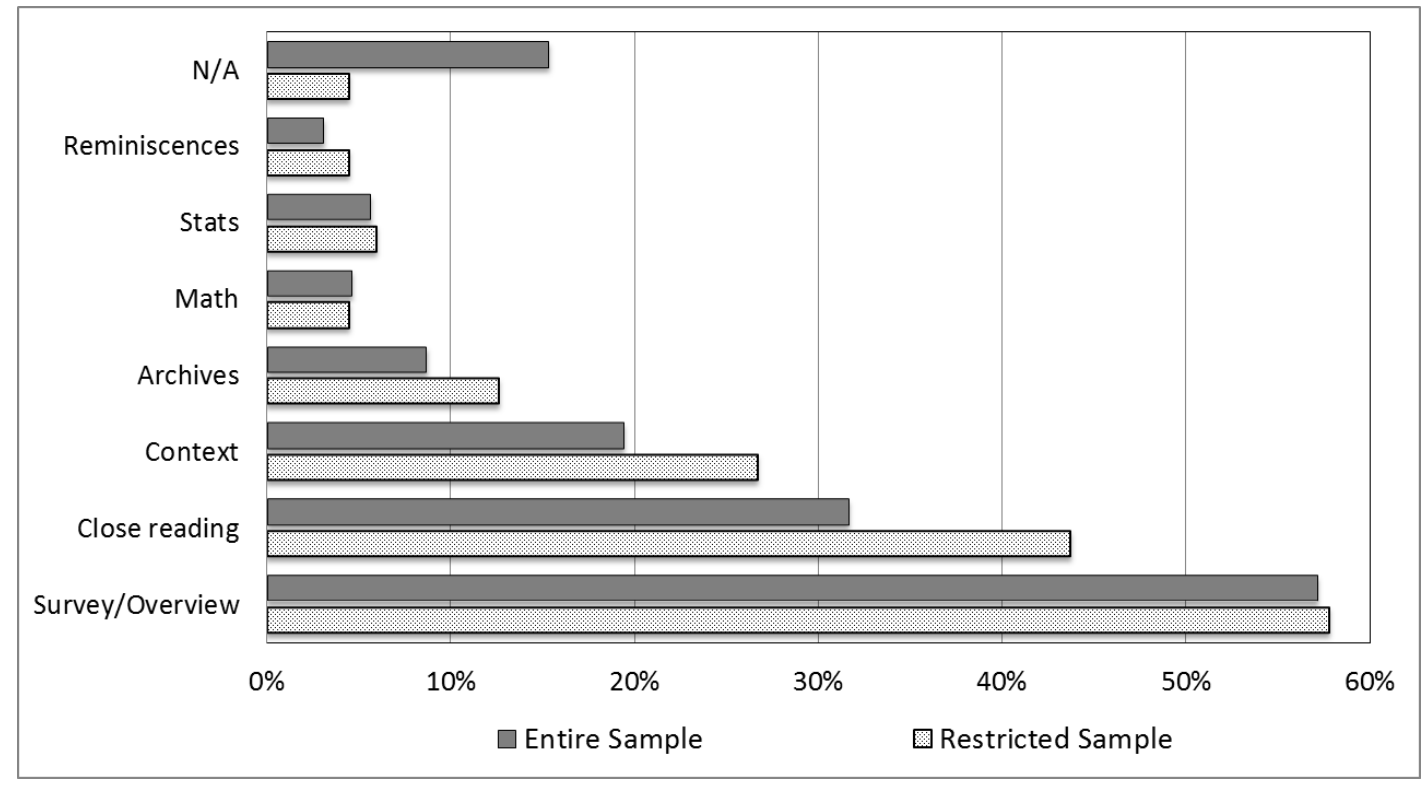

Figure 8: Methods Used in HET Articles for All Journals

\footnotetext{
${ }^{20}$ Figures 8 and 9 record the number of times a given method appeared divided by the number of articles (category 5) in our sample. As one article can have multiple methods, the sum of the percentages in these figures is greater than $100 \%$.
} 


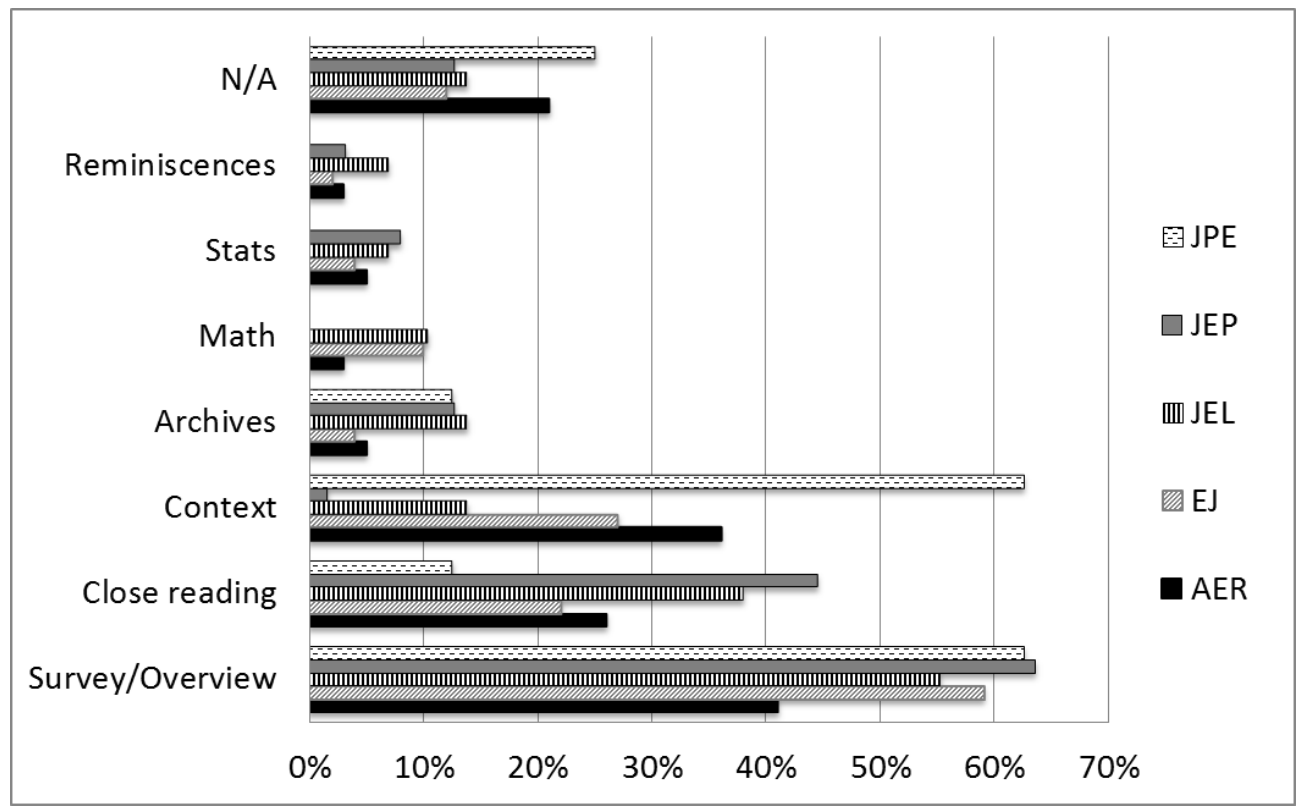

Figure 9: Methods used in HET in Selected Journals (entire sample)

It is quite revealing that the method mostly represented in these articles is 'Survey and Overview', which is also the least specific tool that can be used in the context of a historical work. While $57 \%$ of all studied papers (in all journals) proceed by surveying the literature or expressing general statements over the development of economic thought, only $32 \%$ attempted to interpret the texts by providing direct quotations from them. Only few articles use archival materials as evidence to ground their claims on the history of economics. In fact, there are fewer articles using the archives (9\%) than articles whose method appear as not historical at all ("N/A" method; 15\%). The same observation applies for use of mathematics or statistics, which rarely occurs in these papers (5\%). Figure 9 shows that there are a few journalspecific traits, such as a more frequent use of close reading in the articles published in the JEP and relatively more efforts to contextualize past economic ideas in the few papers published in the $J P E$.

Considering the high numbers of ' $\mathrm{N} / \mathrm{A}$ ' results - papers which do not use a method we could consider as 'historical' - it is necessary to show what happens when we remove from our sample the articles that are not labeled with a B0 to B3 JEL descriptor. The results are also shown in Figure 8. Unsurprisingly we see a smaller portion of 'N/A' items, which shows that most of these were in the B4 and B5 subcategories. However, the hierarchy among other methods is not significantly affected. 
Next, to come up with what we designate as 'narrative styles', we had to ask the question: "why was this piece published in the first place?" or "what is there in this piece that is interesting enough to the economists' community to justify publication in a major economic journal?" While some of these papers address the question quite openly, explicitly stating the reasons why economists should pay attention to some past economic theory or author, we must recognize that most of the surveyed articles do not provide such statement. It is especially the case when these papers deal with a great figure from the past. The reason for which the reader is expected to be interested in a given argument about Adam Smith or David Ricardo is that these authors are considered as founding fathers of the discipline. Yet the idea itself is rarely discussed but rather taken for granted. For this reason, some of the following 'narrative styles' needed to be reconstructed by finding these missing justifications between the lines. After reading and summarizing the research articles published in all sampled journals, we came across the following eight narrative styles:

- Assessment: Historical elements are invoked either as a way to judge past ideas in retrospect or to assess the current status of the discipline or of one of its subfields in accordance with historical developments. As an example of this style we mention Samuelson (1994), which offers a critical assessment of the Classical economists' assertion that technological progress will raise wages if it increases the quantity of circulating capital and lower wages if it increases the quantity of fixed capital.

- Foundation: The article traces the origins of current economic ideas in past historical developments, or great figures of the past are designated as founder of some particular literature, current economic trend, or subfield. This is present in Schabas and Wennerlind (2011), who point to the relevance of Hume's thought to economic issues, as well as in Myerson (1999), who provides an account of the importance of Nash's non-cooperative game theory in the history of economic thought, arguing that Nash's theory has been responsible for shifting the emphasis of economics from the study of the production of material goods to that of rational decision-making.

- Literature review: Past references are invoked as a way to give a nonjudgmental account of the development of some current subfield of the discipline. As an example, we cite Williamson (2000), who provides a survey of the new institutional economics literature. 
- Anecdote: The article tells an anecdote regarding past economic figures or explores a not crucial detail of his (academic) life or career. This is done for instance in Sandmo (2007), who tells the story of Léon Walras's unsuccessful attempt to be awarded the Nobel Peace Prize.

- Testimony: An economist tells a personal account of some past development. Here we have, for instance, Samuelson (1998), who offers a personal account of the making of his book Foundations of Economic Analysis.

- Deconstruction: In some way, this narrative style is the contrary of 'Foundation'. Here, past economic texts are historically/methodologically/rhetorically deconstructed so as to qualify/alter canonical interpretations of such texts or the received views on their role in the history of economics. One example is Ekelund and Hebert (2002), who emphasize the contribution of French engineers to economic theory in the mid-nineteenth century to argue against the received view that neoclassical economics was developed in the 1870s through the writings of Menger, Jevons and Walras. Another example is Moggridge (1992), who discusses the commonly accepted origins of the term animal spirits used by Keynes.

- Prospective speculation and anniversaries: It refers to the use of past texts/ideas/authors in a narrative that aims to ponder on the future trends of a field or branch of literature. An example of this style is provided in our sample by most articles from the $Q J E$, offering at the turn of the century an account of what we know and what comes forward. This category also includes articles using the past due to an important anniversary of an economist, an idea, or an institution - like a journal, professional association, etc., for instance the centennial of the Royal Economic Society in the EJ in 1991.

- N/A: A mostly non-historical account (theory article, methodology, heterodox economics without explicit historical roots).

The next two figures show how these various narrative styles are distributed among the surveyed articles (category 5 only): ${ }^{21}$

\footnotetext{
${ }^{21}$ It happened that we assigned one style to most articles, so that the sum of frequencies in figures 11 and 12 is $102 \%$.
} 


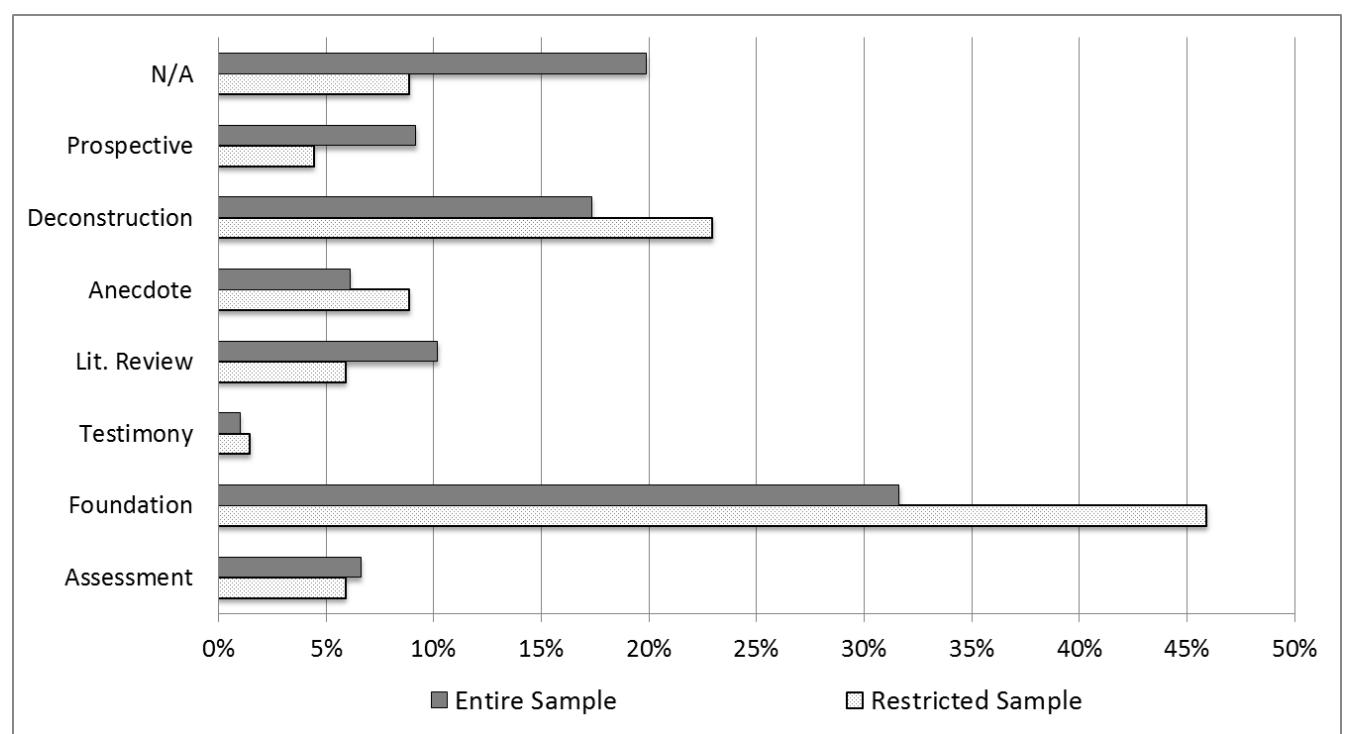

Figure 10: Narrative Styles in All Journals

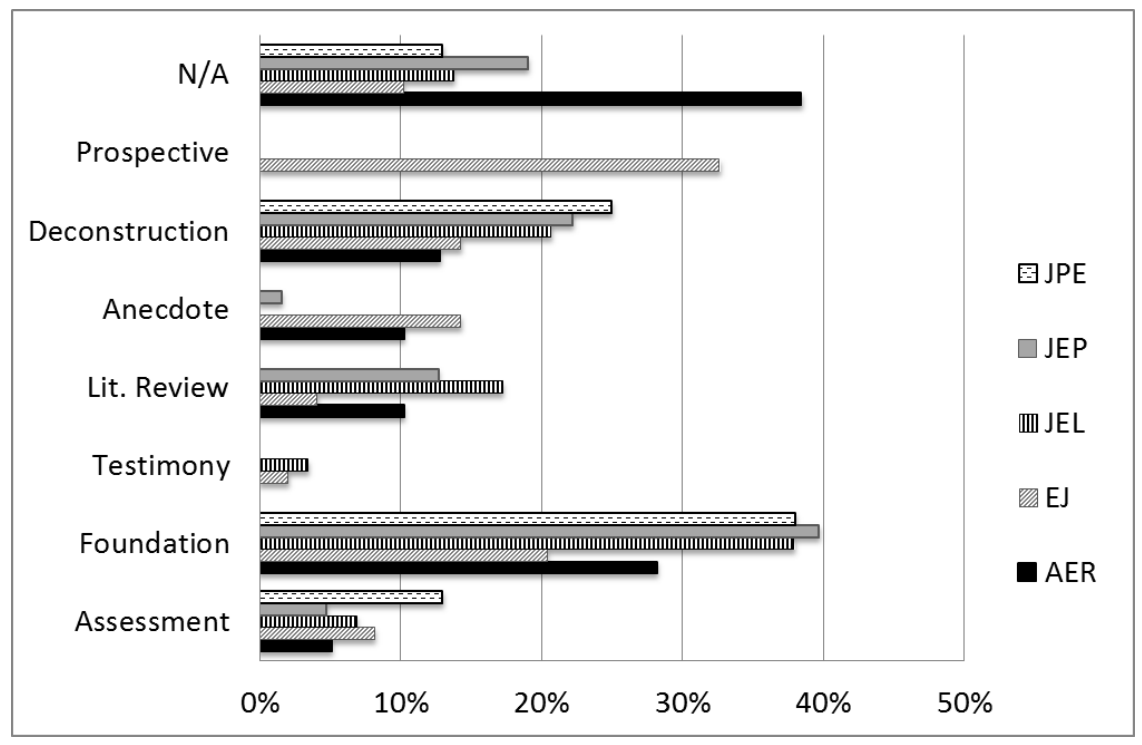

Figure 11: Narrative Styles in Selected Journals (entire sample)

One salient result is the high number of articles that do not really provide a historical narrative but rather expose a theoretical or methodological argument ("N/A" style). They represent $20 \%$ of our surveyed sample. ${ }^{22}$ These non-historical contributions put aside, the most frequently encountered argument found in the surveyed articles is the one consisting in designating some great figure of the past as the founder of one subfield of economic theory or as prominent actor in shifting

\footnotetext{
${ }^{22}$ Note that the occurrence of such pieces does not match the B4 (methodology) or B5 (heterodox economics) $J E L$ categories. While there are a number of papers falling under the B4 category that do contain a historical narrative, it is notable that there also exists a number of contributions that have no significance to the history of economics while falling under the more historical B-codes (B0 to B3).
} 
economic theory as a whole - "foundation" represents $32 \%$ of all articles. There are, of course, several variants of this discourse, which can be expressed more or less subtly but all in all the temptation to use the past as a justification for recent economic developments is something which is still widespread in the economics profession, though it was denounced as early as 1969 by A. W. Coats when he wrote $(1969,11)$ :

Too often, instead of providing corrective therapy, historians of economics have exacerbated the complaint either by ransacking the past for evidence of the antecedents of contemporary verities or by concentrating unduly on the immanent development of economic ideas as an autonomous body of theoretical knowledge.

It is not surprising, therefore, that after these foundational pieces, the most frequently encountered discourse on HET $-17 \%$ of our sample -is its contrary: pieces that aim at deconstructing the received view on the origin of past economic theory. For instance, it testifies to the persistence of the received view among economists that Adam Smith's "invisible hand" is the cornerstone of market efficiency theory that there are two distinct contributions in major economic journals - Rothschild (1994) in the AER and Grampp (2000) in the JPE - both denying the validity of such view. Among the other narrative styles, none really stands out, each one representing less than $10 \%$ of the total - in particular, there is very little "testimony" $(1 \%)$.

One interesting observation is the relatively rare occurrence of pieces judging past economic developments with the tools of present-day economics ("assessment"), namely what Samuelson designated as the "Whig History of Economic Analysis" (1987, 52), pointing to Jacob Viner's Studies in the Theory of International Trade (1937) as a suitable example to follow. What we see in our sample is that only $7 \%$ of all published articles attempt to judge past ideas but if we look more closely at these pieces we see that only two papers really use modern economic modeling to assess past ideas and one of them is Samuelson's own 1994 piece on the Classical fallacy over technological change. Though it is undeniable that Whig accounts dominate the literature we surveyed, very few have followed Samuelson's program to do so.

Looking at journal-specific traits, we observe in Figure 11 that some journals such as the $A E R$ had more non-historical contributions among their B-code articles while the JPE published relatively more "deconstruction" pieces than the other 
journals. "Prospective" analyses were present only in the EJ, among the five journals listed in Figure 12 (QJE is the other journal were a few of them appear).

Besides, one salient result is the high number of articles that do not really provide a historical narrative but rather expose a theoretical or methodological argument ("N/A" style). They represent $20 \%$ of our surveyed sample. One question then worth asking is whether these articles are solely located in the B4 and B5 subcategories. Restricting our sample to the B0-B3 range of the JEL descriptors (see Figure 10), we indeed note than a significant portion of these articles disappears. Yet there are still $9 \%$ of the articles bearing a B0 to B3 JEL code that do not really address the history of economics. Moreover, the prominence of "foundational" pieces is even more striking when consider the restricted sample: this kind of narrative style can be found in about half of the published articles.

On the whole, beside the fact that a significant number of pieces show little historical sensitivity toward past economic developments, what these figures reveal is that the majority of the historical literature published in top economics journals is still centered around the idea of foundational myths, whether it is to reinforce or to undermine them.

\section{4 - A closer view}

Given the relatively small size of our sample, we considered necessary to enrich our analysis by looking closer at the few hundred pieces published in the eight journals we surveyed. With this, two questions emerged: Is it possible to locate a few more journal-specific traits and see through the topics addressed in these articles and the opinions expressed by the authors how the role of HET has evolved during our period of scrutiny? Can some of these evolutions be explained by changes in editorship? We address these issues by providing a quick overview of HET in each journal. Because Econometrica, the REStds and QJE contain almost no historical work, they are treated more briefly than the other journals.

\section{The Journal of Economic Perspectives}

The Journal of Economic Perspectives (JEP) is particularly important to our narrative because it has the highest number of historical articles (category 5) published among the eight journals we selected. This is not surprising given that the 
journal was created by the American Economic Association (AEA) in 1986 "to provide a range of perspectives on economics and to show how an economic perspective can help in understanding society and some of its problems" (Stiglitz, Shapiro and Taylor 1987, 3). It features articles for a general audience in a field that has become increasingly specialized. Such articles, generally commissioned, would either synthesize what we know, or present the state-of-the-art of an area of economics or of the theories related to a particular economic question, or would address issues related to the economics profession at large. ${ }^{23}$ When they make these kinds of analyses economists tend to use some type of the historical methods and the narrative styles that we discussed before.

The first issue of the JEP appeared in the summer of 1987, under the editorship of Joseph E. Stiglitz (with Gary S. Becker as the president of the AEA), having some distinctive columns or regular features. The first was a feature on "Anomalies", edited by Richard H. Thaler (then a professor of economics at Cornell), with evidence that is inconsistent with standard economic theory (or the dominant paradigm, to use the concept of Thomas Kuhn, whose words served as epigraph to this column). The second was a feature with "Puzzles", edited by Barry Nalebuff (an assistant professor of economics at Princeton) who intended "to create a dialogue between the journal and its readers" with puzzles selected to either "stimulate research", or to "help undergraduate and graduate teaching", or yet to "provide quality distractions during seminars" (Nalebuff 1987, 185). Finally, there was a bibliographic column where Bernard Saffran (a professor of economics at Swarthmore College) would list articles that are either useful for teachers of undergraduate economics or are of "broader cultural interests" (Saffran 1987, 193).

In 1989 Joseph Persky (then an associate professor of economics at the University of Illinois at Chicago) sent Stiglitz a proposal for adding another column to the journal, "Retrospectives", on the history of economics. Stiglitz, the founding editor of the JEP, and Timothy Taylor (managing editor) were supportive of the idea. Stiglitz asked Persky to write two trial essays for the column, and it was eventually

\footnotetext{
${ }^{23}$ Stiglitz, Shapiro and Taylor $(1987,3)$ wrote that "[t]he pages of the new journal will reflect the wide spectrum of interests, backgrounds, and viewpoints of the members of the American Economic Association." However, several members interviewed in 1988 by an ad hoc committee chaired by William Baumol resented the JEP editorial policy against unsolicited submissions. For them, this policy "invites assignment of the publication opportunities by clique" and it "slants the contents of the journal even more heavily than usual toward the preferences of the editors, in contradistinction to those of the bulk of the AEA members" (Baumol 1990, 492).
} 
created in the Fall of $1989 .{ }^{24}$ Articles were mostly by invitation, although people were encouraged to submit ideas for the section. The "Retrospectives" had the goal of "enrich[ing] and deepen[ing] the workday dialogue of economists" and perhaps "cast[ing] new light on ongoing issues." This section was envisaged to "discuss various topics in the history of economic thought" and to be featured irregularly ("perhaps in every other issue or so") (Persky 1989, 195). Persky was editorially responsible for the "Retrospectives" and served as the contact person for receiving suggestions on topics and authors to be discussed in this column. ${ }^{25} \mathrm{He}$ wrote the first piece published in this section, on Adam Smith's invisible hand, exploring the "modern ring" that it has to argue that historical specificities are central to understanding Smith's arguments.

What is interesting about the historical articles in the JEP in our sample is that a bit more than half of them came out in the "Retrospectives" session, after we exclude those items that had no historical content ("N/A category," which are mostly methodological articles ${ }^{26}$ ). While articles featured in the "Retrospectives" were a bit shorter than regular historical articles published in the JEP (an average of 12 pages in contrast of almost 16 pages of the regular ones), the former had a clear scope of discussing the "vocabulary of economics" (though this purpose was not always adhered to). Among the thirty four items published in this section (seven of which by Joseph Persky) $68 \%$ of them use the "foundation" style, doing a close reading and survey of the literature. They are usually motivated by a modern concern that has historical roots and they covered a wide range of topics: Smith's invisible hand, animal spirits, creative destruction, institutional economics and competition, index numbers, Say's Law, Friedman's monetarism, measurement of utility, the existence proof of general equilibrium, among others (including Hume, Marshall, Mill, and preclassical economics).

\footnotetext{
${ }^{24}$ Curiously, Stiglitz and Shapiro $(1990,479)$ wrote: "In 1990, the Journal intends to start two additional features, one of which will appear in each issue: 'Retrospectives' on topics in the history of economic thought, and 'Policy Watch' on topics of current policy interest." However, the column came into existence in 1989.

${ }^{25}$ Persky mentioned to us that there were cases of people talking to the JEP editor or managing editor with a suggestion for the section. Other times either Persky, or the editor of JEP or someone else associated with the journal made suggestions and they would seek out authors for writing articles.

${ }^{26}$ Almost all of the twelve articles within the "N/A style" in the JEP had a B4 code (economic methodology) combined with another descriptor of the field of interest (micro, macro, econometrics, etc.). Half of them are a symposium on econometrics ("Con out of Economics") published in the Spring of 2010 and motivated as a reaction to Joshua Angrist and Jörn-Steffen Pischke's 2009 book, Mostly Harmless Econometrics: An Empiricist's Companion.
} 
The particular way of blending history with economics implied that around $53 \%$ of the "Retrospectives" articles combined a history of thought descriptor (B0B3) with a "theoretical" descriptor (of the subfield of economics related to the topic at hand). The second most frequent style is "deconstruction", used in $26 \%$ of these articles. Among the JEP articles not published in the "Retrospectives" section (category 5 that had historical content), a lower percentage of them (almost 41\%) had only a history of thought descriptor. However, several of these items were surveys of a particular literature or had a methodological discussion without much historical content: literature review is the style in $41 \%$ of them, followed by deconstruction (29\%), assessment (18\%), and, lastly, foundation (12\%).

There are two other particularities to the $J E P$, when we look to all categories. The first is that it is the only journal in our sample to feature interviews with prominent economists (category 2). Curiously, this only happened in the 2000s with five economists: Zvi Griliches, William Baumol, Edmond Malinvaud, Robert Mundell, and Edmund Phelps. The second singularity is that the JEP is the leading journal for honorary pieces (category 4), all having history of thought JEL descriptors: the JEP publishes regularly long articles written by fellow economists in honor of Nobel Prize winners, John Bates Clark medalists, and distinguished fellows of the American Economic Association.

\section{The Journal of Economic Literature}

The JEL has been peculiar among the journals we studied in publishing a higher number of extended reviews of books dealing with the history of economics or with methodological issues. In fact, while the number of research articles devoted to these topics has decreased dramatically in the second of the two decades we surveyed - there were only 4 of them since 2001 -, 16 extended book reviews among a total of 22 were published during this period. Though it might be too strong to assert that the higher number of book reviews served as a compensation for the decline of articles in the subfield, this at least suggests that these reviews are the main way through which practicing economists are informed about recent historical and methodological advances nowadays. Though we will focus hereafter on these longer reviews or review articles, it must be noted that over the same period, the $J E L$ had 148 shorter book reviews dealing with either HET or the methodology of economics, which represents roughly a third of the retrieved items in all 8 journals. Admittedly, the 
over-representation of book reviews should not be surprising as we can expect that many books devoted to economics will include a chapter or two discussing the history or methodology of their subject matter.

In the beginning of the period we surveyed, the presence of a number of significantly longer reviews testified to the importance that HET had for some practicing economists. James Heckman's eleven-page review of The History of Econometric Ideas by Mary Morgan offers a good illustration of this interest. Heckman's piece showed his deeper knowledge of HET and the larger history of science. In the introduction, the reviewer mentioned among other references Ian Hacking's and Theodore Porter's contributions to the history of quantification and the various conferences, seminars and symposiums through which Morgan had developed her work. On the whole, he praised what he saw as "the foundation for an important new field of knowledge: the history of econometric thought" (Heckman 1992, 876). However, his discussion of Morgan's book increasingly turned into an appraisal of Trygve Haavelmo's role in the history of econometrics. Heckman's main argument there was that Morgan had overestimated Haavelmo's importance in this history, leaving aside a number of contributions by others, especially those made outside of the Cowles commission. This criticism clearly reflected his discontent with recent trends in structural econometrics which, he thought, tended to inhibit reflection on the models being tested. ${ }^{27}$ Though Heckman did not explicitly discuss the place of HET in economics, the tone of his review made it clear that he believed that historical investigation could help shed light on the current state of the economics discipline.

Conversely, Blaug's twelve-page review of Don Moggridge's and Skidelsky's biographies of Keynes represented an attempt by an historian to show the merits of HET to the economics profession at large, highlighting in particular the role of context and biographical elements in explaining theoretical developments. He wrote: "The origins of a theory, the intentions of the creator of that theory, the biases and unexpressed ideological underpinnings of a writer's thoughts, may influence the way in which the theory is expressed and these rhetorical over- and undertones of a theory may influence its acceptance or rejection by contemporaries, in which case the context of discovery spills over into the context of justification" (Blaug 1994: 120415). Blaug's review, however, was very much an attempt at canonizing Keynes, its

\footnotetext{
${ }^{27}$ Oddly enough, the title of the review article emphasized Haavelmo's canonization as the main founder of "modern econometrics", which seemed to undermine Heckman's main point in the review.
} 
ultimate claim being the centrality of the 'Keynesian avalanche' to modern economic theory, which, he argued, Moggridge and Skidelsky had not sufficiently covered in their respective accounts. ${ }^{28}$

Likewise, the majority of book reviews in our sample are devoted to individuals or groups of individuals - for instance, Alfred Marshall, Joan Robinson, Janos Kornai, or Arthur Lewis - rather than to subfields or movements within economics, which is indicated by the fact that 14 of the 22 items in our sample are tagged with a B3 code. Among these books, biographies and recollections predominate. However, a number of these longer book reviews seem to signal the increasing discrepancy between economists and historians. When UC Berkeley Professor Brad DeLong reviewed the third volume of Skidelsky's biography in JEL, he did not say much about why such biographical work could be of interest to economists. While he praised Skidelsky's "amazingly well-constructed narratives" and the "magnificent portrait of Keynes and his age", DeLong also criticized some of the author's assertions concerning international monetary policies, which he thought should appear as nonsense "to anyone with solid economic moorings" (DeLong 2002, 161-2).

Another sign of this divide between HET and economics was the review of Roger Backhouse's HET textbook The Ordinary Business of Life by Samuel Brittan, a Cambridge educated columnist for the Financial Times. Brittan's appreciation of Backhouse's text showed that his vision of HET and of its methodology was quite different from that of practicing historians. He wrote for instance: "the history of economics is a specialist field in the history of science, and perhaps also a personal hobby or retirement job for economists" (Brittan 2003, 202). Accordingly, most of his review, which was filled with personal considerations on the book's subject matter, seemed to focus on issues related to the scientific status of economics rather than to historical concerns.

More recently, when Martin Shubik reviewed Robert Leonard's account of the creation of Game Theory, he made it clear that even though he found the book to be most stimulating from an intellectual point of view, he would have been more interested in an "objective" account of the most recent changes in this subfield. ${ }^{29}$ It is

\footnotetext{
${ }^{28}$ Admittedly, Skidelsky's third volume of his biography of Keynes had not been published yet.

${ }^{29}$ It is worth noting that Leonard's book is in some way the accomplishment of the work he had previously initiated in a JEL paper (Leonard 1995) and that the latter is probably the medium through
} 
also telling that historians of economics who review books in their subfield often use this exercise as a way to hint at the larger debates within HET and offer their view on them. For instance, Maria Cristina Marcuzzo's review of Nahid Aslanbeigui and Guy Oakes's account of Joan Robinson's academic life was a clear condemnation of the science studies approach to HET as advocated by Weintraub: "Is the Cambridge tradition of economics made less inspiring by the discovery of its embedment in the social construction of doing economics of its time? ... I expect this book will raise dust but I fear it hardly suffices to do justice to the images of Joan Robinson, and of Keynes, and Sraffa, and their standing in the history of economic thought" (Marcuzzo 2010, 460).

All in all these book reviews seem to illustrate a greater estrangement between economists and historians over the years and the growing debates among practicing historians. As for the research articles (category 5) it is quite difficult to identify recurring themes and topics, as there seems to be a wide variety of narratives and methods in the journal. One can just observe an over-representation of papers dealing with Austrian economics - Hayek, Schumpeter, Morgenstern and Popper are all devoted one paper each, another one deals with Austrian economics at large and finally one paper is devoted to the emigration of German-speaking economists after 1933, including a few Austrians. While most of the articles in our sample deal with twentieth century economics, there is a couple of articles devoted to classical economics, including Samuelson's critique of the so-called 'Classical fallacy'. Also, a significant number of articles are devoted to heterodox economics or alternative approaches such as neo-institutionalism and behavioral economics. These contributions are often written by practitioners in these fields and do not appeal much to historical arguments.

The most striking fact, however, is that no B-code article has been published between 2007 and 2010. Actually, if we restrict our sample to the contributions to the history of economics alone (excluding B4 and B5 items), we see that there was no published paper in the subfield between 2004 and 2010 and that, overall, there were only three articles devoted to HET published in the JEL since 2000. The latest contribution has been André Sapir's review article on the theory of European integration intended as a celebration to the fiftieth anniversary of Bela Balassa's 
Theory of Economic Integration, published in 1961. While it refers at times to the history of European integration and contains a few data to assess the importance of Balassa's contribution, it does not make much use of the past literature or more generally of the history of ideas. Contrasting with a greater number of contributions in the 1990s that offered a closer reading of past texts and even occasionally included archival sources (Leonard 1995), JEL in the 'noughties' clearly typified the larger collapse of HET. This seems to correspond to changes in editorship as in 2004 Roger Gordon replaced John McMillan as Editor-in-chief. More interestingly for our purpose, 2006 saw the departure from the Editorial Board of John Whitaker, a specialist in the history of economics who most notably edited the correspondence of Alfred Marshall.

\section{The Economic Journal}

The high total number of items in the B category included in the $E J$ is clearly driven by the very first issue in our sample (January 1991), which is devoted to the centenary of the Royal Economic Society and its journal. On this occasion, John D. Hey, the editor, dedicated an entire volume to the future of economics, with 22 invited contributions addressing the question "The next 100 years?" Out of these, 15 included a B code and are all in category 5, with most of them containing a B4 descriptor only, two had B4 and B2, and two had only a B2 descriptor. Interestingly, when we look at the seven articles in this issue that do not bear a B descriptor, we see that all but two contain historical content. Anyway, 15 articles from this issue in the 64 items in categories 3L-5-6 in EJ for the entire period is substantial (23\%). Given that these 15 articles are all category 5 , they make a much greater proportion of the total number of category 5 items in $E J$, which amount to $49(31 \%)$.

Looking at the total number of articles (in all categories) in $E J$, they are mostly category 5 (52\%); then there are several long obituaries (1L: 32\%); a few long book reviews $(3 \mathrm{~L} ; 9 \%)$, and a few items in category 6 (comments, replies, rejoinders, introductions, errata) (7\%). These category 6 items include replies (authors rectifying the historical interpretation provided by another article), errata, and reply to book reviews. Category 6 is, overall, not very significant (20 items in all journals), but it is basically present in the $J E P$ and $E J$. For the obituaries, they are not a very significant category as well (41 items in all journals), but they appear mostly in the $E J$ and $J P E$, all as longer articles. Finally, all book reviews in $E J$ in our sample are long and the 
majority of them (75\%) were published in the 1990s, when Roger Backhouse was the book review editor (form 1990 to 2000). ${ }^{30}$ These reviews discussed a wide range of books, from Philip Mirowski's More Heat Than Light, to Richard Kahn's The Economics of the Short Period (Fellowship Dissertation), passing through Bruna Ingrao and Georgio Israel's The Invisible Hand, Keynes's biographies, books on economic methodology and on Marshall, as well as Ken Binmore's Game Theory and the Social Contract. ${ }^{31}$

For the category 5 items, which are the vast majority of the papers published in the $E J$, there are some interesting aspects. First, there were some special sessions (with invited papers) that were published in the $E J$ and had historical papers (a total of twenty three articles, fifteen of which from the 1991 issue): besides the 1991 issue on the journal's centenary, there was one session in 1998 on formalism in economics (with contributions by Roger Backhouse, Victoria Chick, Paul Krugman, and E. Roy Weintraub), one on experimental economics in 1999, and one in 2005 on computability and evolutionary complexity. ${ }^{32}$ There is an overall presence of more modern (post 1930s) themes (choice theory and psychology, permanent income, Keynesianism, game theory, and rational expectations are some examples), though there are a few papers on Turgot, Smith, Hume. Several of the "modern" papers are related to some degree to important economists who were either British or had a career mostly in British universities: Sraffa, Keynes, Marshall, Meade, Kahn, Phillips, Pigou, Richard Stone, Kenneth Boulding, and Joan Robinson. Some of these articles were in fact relatively long obituaries published more than five years after the economist's death. The number of occurrences of such obituaries is a distinctive feature of the $E J$ among the journals in our sample.

In terms of the editorship of the $E J$ in this period, John D. Hey (who was in his early 40s when took office) served as editor from 1986 to 1996, having a small group of three associate editors, all with British affiliations. In 1997 a new editorial structure was adopted, with four to six people serving as editors, with individuals in different

\footnotetext{
${ }^{30}$ The other two book reviews (there were eight in total) were published in 2001 and 2003 . The first of them was most likely commissioned still by Backhouse.

${ }^{31}$ The Economic Journal publishes also several short book reviews, among which there are methodology and history of thought books. However, these items were not included in our sample because they did not have a JEL descriptor.

${ }^{32}$ In the case of the last two sessions, only half of the papers had a B JEL descriptor and are included in our sample. These papers make a survey and overview and add some historical content to their analysis according to our approach.
} 
stages in their careers, and with a much larger group of associate editors (twelve or more), now including scholars working in other European countries and in the US.

\section{The American Economic Review}

If it were not for its annual "Papers and Proceedings" issue (P\&P), the $A E R$ would not be considered much open to HET: among a total of 39 articles (category 5) published in this journal, only 7 are not proceedings from the AEA annual conference. Two of these papers are presidential addresses and two others are published on the occasion of the centennial of the AER. That leaves us with only three regular articles bearing a B code. The latest of the three was published in 2011 but it is a paper on falsifiability that falls into the B4 category and does not contain a historical argument. The two other papers were published in 1992 and 1994 respectively and both provide a rather contextual account of the history of the discipline using archival materials, both belonging to the "deconstruction" narrative style. The first is Samuel Hollander's paper on Thomas Malthus argues against the traditional interpretation of the renowned Classical economist as a defender of landowners who advocated protectionism without reservation (Hollander 1992). The second is by Beat Burgenmeier who deconstructs the idea that Léon Walras was solely a mathematical and neoclassical economist, and depicts him as a pioneer in socio-economics (Burgenmeier 1994). Yet, apart from these two contributions, the AER does not fare much better as a receptacle for HET than the QJE or Econometrica. The centennial pieces are not really historical. One provides a rather theoretical account of the creation of the $A E R$, describing the AEA as an organization providing goods and services to its members, one of them being the $A E R$. The other paper in this series is a discussion of the twenty most "influential" articles published in the AER since its creation according to a panel of eminent economists including Kenneth Arrow, Martin Feldstein, James Poterba and Robert Solow. The papers are here discussed for their theoretical merits and the fact that they have been cited often is the main reason justifying their inclusion in the list. However, the authors do not really try to assess the significance of these papers in the history of the discipline - there is no justification, for instance, for the lack of pre-WWII papers - hence the quite unhistorical character of this piece (Arrow et al. 2011).

As for the P\&P pieces, they mostly reflect the presence at the AEA meeting of a number of sessions (but not those sponsored by the History of Economics Society) 
devoted to historical or methodological issues, though all the articles published from these sessions are not necessarily associated to a B descriptor. Among the significant AEA sessions included are a set of papers dealing with "invisible-hand theories" in 1994. Among them, despite the obvious reference to Adam Smith in the title, only one paper (Rothschild 1994) deals with the historical literature per se while the other papers are more methodological than historical in content.

In 1997, six contributions were published as part of a symposium celebrating the fiftieth anniversary of Irving Fisher's death. Most of these contributions are appraisals of Fisher's contribution to various subfields of economic theory and policy. Increasingly, however, the historical element in the P\&P begins to fade away at the turn of the century. The contributions signaled with a B code are increasingly related to methodological and sociological concerns within the discipline. It is the case of a number of papers dealing with the evolutionary and biological aspects of economics, whereas two papers are devoted to the place of women in economics, giving an historical overview of feminist economics and emphasizing the role that Harriett Taylor Mill had on the economic ideas of her husband, John Stuart Mill (Seiz and Pujol 2000). Since then, only two truly historical pieces were published: François Velde, in a 2007 paper, provided a historical analysis of John Law's contribution to monetary economics, whereas Benjamin Friedman's 2011 piece dealt with the influence of religion on $18^{\text {th }}$ century economic thought. In the other cases, the $\mathrm{B}$ descriptor seems to signal that the author is attempting to review the literature or more simply, that the paper is either a methodological or a heterodox contribution.

Overall, the AER's openness to HET is quite limited - and has become increasingly so over our twenty-year period. One of the reasons we can suggest to explain this evolution is the fact that if one historical contribution had sufficient appeal to the economics' profession at large, its author would probably be encouraged to submit it to the Journal of Economic Perspectives instead.

\section{The Journal of Political Economy}

The JPE is not a major outlet for historical papers. Nonetheless, history of economics appears there in particular ways. This journal, together with the $E J$, is one of the few to feature long obituaries. Here for a good reason: in 1993 the journal dedicated its October issue to the memory of George J. Stigler, who was a Chicago professor and the editor of $J P E$ from 1972 until his death in December of 1991. Ten 
of the fourteen articles in this issue were personal recollections and retrospectives on Stigler's work written by economists, the majority of whom had close ties to the University of Chicago, either working at the economics department or having done graduate work there - W. Allen Wallis (former professor and student), Milton Friedman (professor), Gary S. Becker (professor; PhD 1955), Claire Friedland (professor; MA 1955), Sam Peltzman (professor; PhD 1965), Sherwin Rosen (professor; PhD 1966), and Thomas Sowell (PhD 1968). The only two who had no such ties were Harold Demsetz and Nathan Rosenberg. Besides these obituaries, JPE (together with the $J E P$ and the $A E R$ ) featured Nobel lectures: out of the three items in category 4L, two were written by eminent Chicago professors, Robert Lucas (in 1996) and James J. Heckman (in 2001) - the last lecture, in 2006, was by Edward Prescott, who was a student of Lucas at Carnegie Mellon in the mid-1960s.

Besides Stigler's memorial and the Nobel lectures, the JPE published only seven historical articles (plus one on institutional economics with a B5 descriptor), scattered throughout the period under analysis. The majority of these articles had a relation to the University of Chicago. Some dealt with the Chicago tradition in economics (on economic fluctuations and monetary theory), while others dealt with themes that are central to eminent Chicago professors, such as Friedman's monetarism (with an article claiming that Irving Fisher was a precursor to Friedman and Schwartz's thesis that there was a power vacuum at the Fed in the 1930s; another analyzing David Hume's monetary thought). A Chicago connection appears also in the authors of two of these historical articles, who obtained their PhD there: David Laidler and William D. Grampp.

There are three other articles, one discussing Pareto's Walrasian roots, another providing a context for understanding Adam Smith's invisible hand, and one theoretical paper with a real business cycle model simulated to criticize Keynes's recommendation of taxing capital income highly in Britain (showing instead that a tax smoothing policy would improve welfare). It is interesting that the majority of these seven articles provided a historical contextual analysis, with the one on Fisher even using archival resources. Nonetheless, the need for having some sort of theoretical point shows up in the percentage of articles (categories $3 \mathrm{~L}, 5$, and 6) that has a B JEL descriptor combined with a non-B descriptor: JPE has the highest number $(63 \%)$ among the journals in our sample when we disregard the Quarterly Journal of 
Economics and Review of Economic Studies that published very few historical articles (see Table 2).

The Quarterly Journal of Economics, Econometrica, and the Review of Economic Studies

The QJE, Econometrica, and the REStds published very few historical papers. The very small number of articles and the very idiosyncratic motivations for publishing them make the case for very little openness to historical analysis in these journals in the period 1991-2011. QJE published five historical articles in a single year: 2000. Exploring the turn of the century, the journal invited five noted economists to make an overview of their field and what is expected to come in the new century: Baumol on economics more generally (comparing modern developments to what was known to Alfred Marshall); Heckman on the econometrics of causal parameters (identification problem and policy evaluation); Olivier Blanchard on macroeconomics; Samuel Bowles on social norms and strategic market interactions (comparing these developments with Walrasian economics); and Stiglitz on the economics of information. Econometrica published only two articles, one theoretical analysis on choice theory (that had a methodology descriptor, B4), and one very rich historical paper (an eleven-page piece) by Olav Bejerkholt on the founding of the journal and Ragnar Frisch's editorship, published in 1995, the year of Frisch's centennial. In its turn, REStds published just one theoretical paper on collective-action games that bore an institutional/evolutionary JEL descriptor.

\section{5 - Concluding Remarks: Reasoning at the Margin}

The preceding account depicts publication in major economics journals as a plausible yet quite unreliable strategy for the future development of the history of economic thought. Though historical pieces are still regularly published in top economics journals, the rate of publication of such papers has become increasingly uneven, with a clear declining trend in some journals. While the JEL published one article dealing with historical issues in 2011, it had not done so since 2006. In the EJ no historical article has been published since 2007 . Historical papers are very unlikely to appear in either Econometrica, QJE, or the REStds. 
Many disciplinary historians have been inclined to blame mainstream economists for the situation, as if the latters have refused to publish a steady flow of historical articles submitted to economics journals. These historians believe that not paying enough attention to the history of the field not only indicates a lack of cultural interest toward the past but also impoverishes economic theory itself - see Kates (2013), for a recent restatement of this critique. Our study suggests that historians of economics themselves might also be partly responsible for the poor status in which their subfield is held by the economics profession, for in the 1990s they were still able to publish historical papers at a quite steady pace - the missing part of the story is the number of submissions by historians to economics journals.

Moreover, the fact that too many contributions to HET relied not on specific tools and methodologies but rather on surveys and quite general statements may have contributed to the conflation of historical investigations and literature surveys. As economics is still witnessing increased specialization and technicalization, it is more rewarding for an editor of a quite generalist journal to publish a survey or a retrospective piece written by a specialist rather than a historical piece whose method or focus does not seem to be located at the frontiers of knowledge. That the central issues in the latest developments in the history of economics - for instance the idea that economic knowledge is produced within communities as opposed to isolated individuals - and the new tools that are being used to address them - a more systematic use of the archives, bibliometric and network analyses - have not yet made their way into the general economics literature is a concern in itself.

Besides, the widespread idea that in order to get closer to the economists, historians should embrace modern economic tools and formulate past economic theories mathematically has not been the practice so far because only a handful of articles doing so have been in major economics journals. It is quite telling in this respect that the only truly historical piece published in Econometrica over the past twenty years, Bjerkholt (1995), offers a non-technical account of the role of Ragnar Frisch in the creation of the journal. Ultimately and quite independently of the question as to whether HET should be considered as a subfield of economics, historians interested in addressing the economics' community should be more interested in expanding the frontiers of their subject matter rather than in trying to anticipate their targeted readers' preferences. 


\section{References}

Arrow, Kenneth and B. Douglas Bernheim, Martin S. Feldstein, Daniel L. McFadden, James M. Poterba and Robert M. Solow. 2011. 100 Years of the American Economic Review: The Top 20 Articles. American Economic Review, 101 (1): 1-8. Backhouse, Roger and Philippe Fontaine. Forthcoming. From One Identity Crisis to Another: Is History of Economics What Historians of Economics Do? In Roger Backhouse and Philippe Fontaine, eds. The Historiography of Modern Social Sciences. Cambridge: Cambridge University Press.

Baumol, William J. 1990. Report of the Ad Hoc Committee on the Journal of Economic Perspectives. American Economic Review, 80 (2, Papers and Proceedings): 492-95.

Bjerkholt, Olav. 1995. Ragnar Frisch, Editor of Econometrica, 1933-1954. Econometrica, 63 (4), 755-65.

Blaug, Mark. 1990. On the Historiography of Economics. Journal of the History of Economic Thought, 12: 27-37. 1204-15.

1994. Recent Biographies of Keynes. Journal of Economic Literature, 31 (3): . 1997. Economic Theory in Retrospect. $5^{\text {th }}$ edition. Cambridge University Press.

1999. Misunderstanding Classical Economics: The Sraffian Interpretation of the Surplus Approach. History of Political Economy, 31 (2): 213-36.

. 2001. No History of Ideas, Please, We're Economists. Journal of Economic Literature, 15 (1), 145-64.

Boulding, Kenneth. 1971. After Samuelson, Who Needs Adam Smith? History of Political Economy, 3 (2): 225-37.

Brittan, Samuel. 2003. Review of The Ordinary Business of Life by Backhouse. Journal of Economic Literature, 41 (2): 202-6.

Burgenmeier, Beat. 1994. The Misperception of Léon Walras. American Economic Review, 84 (1): 342-52.

Card, David and Stefano DellaVigna. 2013. Nine Facts about Top Journals in Economics. Journal of Economic Literature, 51 (1): 144-61. 
Coats, A. W. 1969. Research Priorities in the History of Economics. History of Political Economy, 1 (1): 9-18.

De Long, Bradford. 2002. Review of Skidelsky's John Maynard Keynes: Fighting for Britain. Journal of Economic Literature, 40 (1): 155-62.

Ekelund, Robert and Robert Hebert. 2002. The Origins of Neoclassical Microeconomics. Journal of Economic Perspectives, 16 (3): 197-215.

Friedman, Benjamin M. 2011. Economics: A Moral Inquiry with Religious Origins. American Economic Review, 101 (3): 166-70.

Goodwin, Craufurd D. 2008. History of economic thought. In Steven N. Durlauf and Lawrence E. Blume, eds. The New Palgrave Dictionary of Economics. $2^{\text {nd }}$ ed (online). Palgrave Macmillan. $<$ http://www.dictionaryofeconomics.com/article?id=pde2008_H000174> Accessed on November 15, 2013.

Goodwin, Craufurd D., Joseph J. Spengler and Robert S. Smith. 1969. Avant-Propos. History of Political Economy, 1 (1): 1-4.

Grampp, William. 2000. What Did Smith Mean by the Invisible Hand? Journal of Political Economy, 108 (3): 441-65.

Heckman, James J. 1992. Haavelmo and the Birth of Modern Econometrics: A Review of The History of Econometric Ideas by Mary Morgan. Journal of Economic Literature, 30 (2): 876-86.

Hollander, Samuel. 1992. Malthus's Abandonment of Agricultural Protectionism: A Discovery in the History of Economic Thought. American Economic Review, 82 (3): $650-9$.

Kalaitzidakis, Pantelis, Mamuneas P. Theophanis and Stengos Tanasis. 2011. An Updated Ranking of Academic Journals in Economics. Canadian Journal of Economics, 44 (4): 1525-1538.

Kates, Steven. 2013. Defending the History of Economic Thought. Cheltenham, UK: Edward Elgar.

Leonard, Robert J. 1995. From Parlor Games to Social Science: Von Neumann, Morgenstern, and the Creation of Game Theory, 1928-1944. Journal of Economic Literature, 33 (2): 730-61.

Marcuzzo, Maria Cristina. 2008. Is History of Economic Thought a "Serious" Subject? Erasmus Journal for Philosophy and Economics, 1 (1): 107-123. 
2010. Review of The Provocative Joan Robinson: The Making of a

Cambridge Economist by Nahid Aslanbeigui and Guy Oakes. Journal of Economic Literature, 48 (2): 456-60.

Myerson, Roger B. 1999. Nash Equilibrium and the History of Economic Theory. Journal of Economic Literature, 37 (3): 1067-82.

Moggridge, Donald E. 1992. The Source of Animal Spirits. Journal of Economic Perspectives, 6 (3): 207-9.

Moscati, Ivan. 2008. More Economics, Please: We're Historians of Economics. Journal of the History of Economic Thought, 30 (1): 85-92.

Nalebuff, Barry. 1987. Puzzles: Noisy Prisoners, Manhattan Locations, and More. Journal of Economic Perspectives, 1 (1): 185-91.

Persky, Joseph. 1989. Retrospectives: Adam Smith's Invisible Hands. Journal of Economic Perspectives, 3 (4): 195-201.

. 1992. Pareto's Law. Journal of Economic Perspectives, 6 (2): 181-92.

Rothschild, Emma. 1994. Adam Smith and the Invisible Hand. American Economic Review. 84 (2), 319-22.

Saffran, Bernard. 1987. Recommendations for Further Reading. Journal of Economic Perspectives, 1 (1): 193-5.

Samuelson, Paul A. 1987. Out of the Closet: A Program For the Whig History of Economic Science: Keynote Address at History of Economics Society Boston Meeting, June 20, 1987. Journal of the History of Economics Thought, 9 (1): 5160 .

1994. The Classical Classical Fallacy. Journal of Economic Literature, 32 (2): 620-39.

. 1998. How Foundations Came to Be. Journal of Economic Literature, 36 (3): $1375-86$.

Sandmo, Agnar. 2007. Léon Walras and the Nobel Peace Prize. Journal of Economic Perspectives, 21 (4): 217-28.

Schabas, Margaret and Carl Wennerlind. 2011. Hume on Money, Commerce, and the Science of Economics. Journal of Economic Perspectives, 25 (3): 217-30.

Seiz, Janet A and Michele A. Pujol. 2000. Harriet Taylor Mill. American Economic Review, 90 (2): 476-9. 
Shubik, Martin. 2011. Review of Von Neumann, Morgenstern, and the Creation of Game Theory: From Chess to Social Science, 1900-1960 by Robert Leonard. Journal of Economic Literature, 49 (2): 436-40.

Stiglitz, Joseph, and Carl Shapiro. 1990. Report of the Editor: Journal of Economic Perspectives. American Economic Review, 80 (2, Papers and Proceedings): 479-80.

Stiglitz, Joseph, Carl Shapiro, and Timothy Taylor. 1987. Foreword. Journal of Economic Perspectives, 1 (1): 3-5.

Tubaro, Paola and Erik Angner. 2008. Mini Symposium. The Future of History of Economics: Young Scholars' Perspective. Journal of the History of Economic Thought, 30 (1): 81-4.

Waterman, Anthony. Two Kinds of 'History of Economics'. History of Economic Ideas, 16 (3): 106-11.

Weintraub, E. Roy. 2002. Will Economics Ever Have a Past Again? In E. Roy Weintraub, ed. The Future of The History of Economics. HOPE Annual Supplement 34. Durham, NC: Duke University Press, 1-14. . 2007. Economic Science Wars. Journal of the History of Economic Thought, 29 (3): 267-82. 


\section{Appendix A: JEL classification System - B Codes}

(Source: www.aeaweb.org/econlit/jelCodes.php?view=jel\&print)

\section{B. History of Economic Thought, Methodology, and Heterodox Approaches}

B00 General

B1 History of Economic Thought through 1925

B10 General

B11 Preclassical (Ancient, Medieval, Mercantilist, Physiocratic)

B12 Classical (includes Adam Smith)

B13 Neoclassical through 1925 (Austrian, Marshallian, Walrasian, Stockholm School)

B14 Socialist $\bullet$ Marxist

B15 Historical • Institutional • Evolutionary

B16 Quantitative and Mathematical

B19 Other

B2 History of Economic Thought since 1925

B20 General

B21 Microeconomics

B22 Macroeconomics

B23 Econometrics - Quantitative and Mathematical Studies

B24 Socialist $\bullet$ Marxist $\bullet$ Sraffian

B25 Historical - Institutional • Evolutionary $\bullet$ Austrian

B26 Financial Economics

B29 Other

B3 History of Economic Thought: Individuals

B30 General

B31 Individuals

B32 Obituaries

B4 Economic Methodology

B40 General

B41 Economic Methodology

B49 Other

B5 Current Heterodox Approaches

B50 General

B51 Socialist • Marxian - Sraffian

B52 Institutional $\bullet$ Evolutionary

B53 Austrian

B54 Feminist Economics

B59 Other 
Appendix B:

HET papers published in the Journal of Economic Literature (1991-2011)

\begin{tabular}{|c|c|c|c|c|c|c|c|c|c|}
\hline AUTHOR & Title & Year & vol & nbr & SP & EP & Subject & Argument & Methods \\
\hline Caldwell, Bruce J. & Clarifying Popper & 1991 & 29 & 1 & 1 & 33 & Popper & $\begin{array}{l}\text { An assessment of Popper's falsificationism, situational } \\
\text { analysis and critical rationalism and of their relevance (or } \\
\text { lack thereof) to economics. }\end{array}$ & Close reading. \\
\hline Stigler, George J. & Charles Babbage $(1791+200=1991)$. & 1991 & 29 & 3 & 1149 & 1152 & Babbage & $\begin{array}{l}\text { A depiction of Charles Babbage's contribution to economic } \\
\text { theory. }\end{array}$ & Close reading. \\
\hline Scherer, F. M. & Schumpeter and Plausible Capitalism & 1992 & 30 & 3 & 1416 & 1433 & Schumpeter & $\begin{array}{l}\text { An assessment of how modern economic theory has } \\
\text { responded to Schumpeter's views on R\&D, competition and } \\
\text { monopoly. }\end{array}$ & Survey, close reading. \\
\hline Bloomfield, Arthur I. & $\begin{array}{l}\text { On the Centenary of Jacob Viner's } \\
\text { Birth: A Retrospective View of the Man and His } \\
\text { Work }\end{array}$ & 1992 & 30 & 4 & 2052 & 2085 & Viner & $\begin{array}{l}\text { A depiction of Jacob Viner's academic life and contribution } \\
\text { to economics. }\end{array}$ & $\begin{array}{l}\text { Close reading, archives, } \\
\text { autobiography. }\end{array}$ \\
\hline Christ, Carl F. & $\begin{array}{l}\text { The Cowles Commission's } \\
\text { Contributions to Econometrics at Chicago, } 1939\end{array}$ & 1994 & 32 & 1 & 30 & 59 & Econometrics & $\begin{array}{l}\text { A depiction and assessment of the Cowles Commission's } \\
\text { contribution to econometrics. }\end{array}$ & Survey. \\
\hline Samuelson, Paul A. & The Classical Classical Fallacy & 1994 & 32 & 2 & 620 & 639 & Classical economics & $\begin{array}{l}\text { A critical assessment of the Classical economists' assertion } \\
\text { that technological progress will raise wages if it increases } \\
\text { the quantity of circulating capital and lower wages if it } \\
\text { increases the quantity of fixed capital. }\end{array}$ & $\begin{array}{l}\text { Survey, close reading, } \\
\text { mathematical restatement. }\end{array}$ \\
\hline Stigler, Stephen M. & $\begin{array}{l}\text { Some Correspondence on } \\
\text { Methodology between Milton Friedman and } \\
\text { Edwin B. Wilson; November }\end{array}$ & 1994 & 32 & 3 & 1197 & 1203 & Friedman & $\begin{array}{l}\text { Transcripts of correspondences between Friedman and E.B. } \\
\text { Wilson that shed light on the making of Friedman's } 1953 \\
\text { Essay. }\end{array}$ & $\begin{array}{l}\text { Archives } \\
\text { (not a real paper, though). }\end{array}$ \\
\hline Nelson, Richard R. & \begin{tabular}{|l|} 
Recent Evolutionary Theorizing \\
about Economic Change
\end{tabular} & 1995 & 33 & 1 & 48 & 90 & Evolutionary economics & $\begin{array}{l}\text { A survey of the literature in the field of evolutionary } \\
\text { economics. }\end{array}$ & Survey (not historical) \\
\hline Leonard, Robert J. & $\begin{array}{l}\text { From Parlor Games to Social Science: } \\
\text { Von Neumann, Morgenstern, and the Creation } \\
\text { of Game Theory, } 1928\end{array}$ & 1995 & 33 & 2 & 730 & 761 & Game theory & $\begin{array}{l}\text { An account of Oskar Morgenstern's and John von } \\
\text { Neumann's intellectual journeys up to their collaboration } \\
\text { on the creation of game theory. }\end{array}$ & Close reading, archives. \\
\hline Maki, Uskali & Diagnosing McCloskey & 1995 & 33 & 3 & 1300 & 1318 & Rhetoric in economics & $\begin{array}{l}\text { An assessment of Donald McCloskey's views on the rhetoric } \\
\text { of economics using analytical philosophy to reconstruct } \\
\text { McCloskey's arguments. }\end{array}$ & $\begin{array}{l}\text { Close reading, analytical } \\
\text { philosophy (methodology, not } \\
\text { history). }\end{array}$ \\
\hline $\begin{array}{l}\text { McCloskey, Deirdre N. } \\
\text { and Ziliak, Stephen T. }\end{array}$ & The Standard Error of Regressions & 1996 & 34 & 1 & 97 & 114 & Econometrics & $\begin{array}{l}\text { Most econometrics papers published in the AER in the } \\
1980 \text { s tended to rely solely on significance tests, therefore } \\
\text { confusing statistical and economic significances. }\end{array}$ & $\begin{array}{l}\text { Statistics, close reading } \\
\text { (methodology, not history). }\end{array}$ \\
\hline Conlisk, John & Why Bounded Rationality? & 1996 & 34 & 2 & 669 & 700 & Bounded rationality & $\begin{array}{l}\text { An assessment of the bounded rationality hypothesis based } \\
\text { on a critical survey of the existing literature. }\end{array}$ & Survey, overview (not history) \\
\hline Griliches, Zvi & $\begin{array}{l}\text { The Discovery of the Residual: } \\
\text { A Historical Note }\end{array}$ & 1996 & 34 & 3 & 1324 & 1330 & Growth theory & $\begin{array}{l}\text { An historical account of the origins of the idea of a } \\
\text { 'residual' factor in growth theory. }\end{array}$ & Survey, overview. \\
\hline Sutton, John & Gibrat's Legacy & 1997 & 35 & 1 & 40 & 59 & Theory of the firm & $\begin{array}{l}\text { A discussion of Robert Gibrat's law that the size of a firm } \\
\text { and its growth are independent. }\end{array}$ & $\begin{array}{l}\text { Survey, overview, some } \\
\text { mathematics. }\end{array}$ \\
\hline
\end{tabular}




\begin{tabular}{|c|c|c|c|c|c|c|c|c|c|}
\hline Kirzner, Israel M. & $\begin{array}{l}\text { Entrepreneurial Discovery and the } \\
\text { Competitive Market Process: An Austrian } \\
\text { Approach }\end{array}$ & 1997 & 35 & 1 & 60 & 85 & Austrian economics & $\begin{array}{l}\text { An internalist account of Austrian economics' contribution } \\
\text { to the theory of competitive markets, viewed as a dynamic } \\
\text { process in which entrepreneurial discovery plays a central } \\
\text { role. }\end{array}$ & $\begin{array}{l}\text { Survey, overview, some } \\
\text { mathematics. }\end{array}$ \\
\hline Whitaker, John K. & $\begin{array}{l}\text { Enemies or Allies? Henry George and } \\
\text { Francis Amasa Walker One Century Later }\end{array}$ & 1997 & 35 & 4 & 1891 & 1915 & $\begin{array}{l}\text { Early American } \\
\text { economics }\end{array}$ & $\begin{array}{l}\text { An account of Francis Walker's and Henry George's } \\
\text { academic lives and works, shedding light on the } \\
\text { professionalization of the American economics profession. }\end{array}$ & Close reading, some context. \\
\hline Caldwell, Bruce & Hayek and Socialism & 1997 & 35 & 4 & 1856 & 1890 & Austrian economics & $\begin{array}{l}\text { An historical account of Hayek's critique of socialism that } \\
\text { explains both why he was critical of market socialism but } \\
\text { also why his framework differs from that of modern } \\
\text { economists of information. }\end{array}$ & $\begin{array}{l}\text { Close reading, context, some } \\
\text { archives. }\end{array}$ \\
\hline Hodgson, Geoffrey M. & $\begin{array}{l}\text { The Approach of Institutional } \\
\text { Economics }\end{array}$ & 1998 & 36 & 1 & 166 & 192 & Instititutional economics & $\begin{array}{l}\text { An account of institutional economics that aims at } \\
\text { distinguishing old from new institutionalism and argues } \\
\text { against previous commenters that old institutionalism did } \\
\text { have a theoretical content. }\end{array}$ & Survey (not much historical). \\
\hline Weintraub, E. Roy & Archiving the History of Economics & 1998 & 36 & 3 & 1496 & 1501 & Methodology of HET & $\begin{array}{l}\text { Though archival materials have received scant attention } \\
\text { from the economics' profession, they are very useful for } \\
\text { both historical and teaching purposes. Therefore, } \\
\text { economists should preserve their papers and offer them to } \\
\text { libraries' special collections. }\end{array}$ & $\begin{array}{l}\text { Methology of HET, not really a } \\
\text { historical paper. }\end{array}$ \\
\hline Samuelson, Paul A. & How Foundations Came to Be & 1998 & 36 & 3 & 1375 & 1386 & Samuelson & $\begin{array}{l}\text { A personal account of the making of Samuelson's } \\
\text { Foundations of Economic Analysis. }\end{array}$ & Autobiographical account. \\
\hline Thomson, William & $\begin{array}{l}\text { The Young Person's Guide to Writing } \\
\text { Economic Theory }\end{array}$ & 1999 & 37 & 1 & 157 & 183 & Methodology & A guide to writing publishable papers on economic theory. & Methodology, not history. \\
\hline Tribe, Keith & Adam Smith: Critical Theorist? & 1999 & 37 & 2 & 609 & 632 & $\begin{array}{l}\text { Adam Smith, historiography of } \\
\text { economics }\end{array}$ & $\begin{array}{l}\text { The author surveys the recent historical literature on Adam } \\
\text { Smith, which considers him less as a founder of economics } \\
\text { than as a critique of the commercial society of his time. He } \\
\text { then discusses the consequences of this new 'historical' } \\
\text { interpretation of Smith. }\end{array}$ & $\begin{array}{l}\text { Survey, close reading, } \\
\text { historiography. }\end{array}$ \\
\hline Myerson, Roger B. & $\begin{array}{l}\text { Nash Equilibrium and the History } \\
\text { of Economic Theory }\end{array}$ & 1999 & 37 & 3 & 1067 & 1082 & Game theory & $\begin{array}{l}\text { An account of the importance of Nash's non cooperative } \\
\text { game theory in the history of economic thought. Nash's } \\
\text { theory, it is argued, has been responsible for shifting the } \\
\text { emphasis of economics from the study of the production of } \\
\text { material goods to that of rational decision making. }\end{array}$ & Survey, overview. \\
\hline Scherer, F. M. & $\begin{array}{l}\text { The Emigration of German-Speaking } \\
\text { Economists after } 1933\end{array}$ & 2000 & 38 & 3 & 614 & 626 & Migration of economists & $\begin{array}{l}\text { Building on recent accounts of the migration of German- } \\
\text { speaking economists to Anglo-saxon countries, this paper } \\
\text { argues that a new environment significantly increased the } \\
\text { academic productivity of these economists. }\end{array}$ & Survey, some econometrics. \\
\hline Williamson, Oliver E. & $\begin{array}{l}\text { The New Institutional Economics: } \\
\text { Taking Stock, Looking Ahead }\end{array}$ & 2000 & 38 & 3 & 595 & 613 & New Institutional economics & $\begin{array}{l}\text { A survey of the New Institutional Economics (NIE) } \\
\text { literature. }\end{array}$ & Survey (not historical). \\
\hline Robson, Arthur J. & $\begin{array}{l}\text { The Biological Basis of Economic } \\
\text { Behavior }\end{array}$ & 2001 & 39 & 1 & 11 & 33 & Evolutionary economics & $\begin{array}{l}\text { An account of the biological foundations of economic } \\
\text { behaviour. }\end{array}$ & Methodology (not history). \\
\hline
\end{tabular}




\begin{tabular}{|c|c|c|c|c|c|c|c|c|c|}
\hline Sen, Amartya & Sraffa, Wittgenstein, and Gramsci & 2003 & 41 & 4 & 1240 & 1255 & Sraffa & $\begin{array}{l}\text { Piero Sraffa's contributions to economics should not be } \\
\text { viewed as separate from his political and philosophical } \\
\text { conceptions. Here, the latter are discussed in relation with } \\
\text { those of his contemporaries, Antonio Gramsci and Ludwig } \\
\text { Wittgenstein. }\end{array}$ & Close reading. \\
\hline Fudenberg, Drew & $\begin{array}{l}\text { Advancing beyond Advances } \\
\text { in Behavioral Economics }\end{array}$ & 2006 & 44 & 3 & 694 & 711 & Behavioral economics & A survey of the recent literature in behavioral economics. & Survey (not historical). \\
\hline Sapir, Andre & $\begin{array}{l}\text { European Integration at the Crossroads: A } \\
\text { Review Essay on the } \\
\text { 50th Anniversary of Bela Balassa's Theory of } \\
\text { Economic Integration }\end{array}$ & 2011 & 49 & 4 & 1200 & 1229 & International economics & $\begin{array}{l}\text { A review and assessment of Balassa's Theory of } \\
\text { Economic Integration(1961) showing its relevance for } \\
\text { today's European economic issues. }\end{array}$ & $\begin{array}{l}\text { Review, overview (not } \\
\text { really historical) }\end{array}$ \\
\hline
\end{tabular}

